\title{
LA EFICACIA EN ESPAÑA DE LOS DIVORCIOS EXTRAJUDICIALES OTORGADOS EN EL EXTRANJERO
}

\section{THE EFFECTIVENESS IN SPAIN OF EXTRA-JUDICIAL DIVORCES GRANTED ABROAD}

\author{
Nuria Marchal Escalona \\ Profesora Titular de Derecho internacional privado \\ Universidad de Granada \\ ORCID: ID 0000-0002-0353-664X
}

Recibido: 14.12.2020 / Aceptado: 11.01.2021

DOI: https://doi.org/10.20318/cdt.2021.5967

\begin{abstract}
Resumen: El objeto del presente trabajo es analizar el régimen de reconocimiento de los divorcios extrajudiciales extranjeros en España considerando como tales aquellos en los que interviene una autoridad no judicial con carácter constitutivo o como mera federataria, así como los basados en un simple acuerdo entre los cónyuges. La importancia cuantitativa que están adquiriendo en los últimos tiempos evidencia el interés del tema y la necesidad de un tratamiento pormenorizado del mismo al no existir estudios doctrinales sobre el tema. Una cuestión que se presenta compleja, máxime teniendo en cuenta que la diversidad es la nota dominante en Derecho comparado, y que la decisión o el documento que disuelve el matrimonio puede incluir pronunciamientos diferentes al meramente constitutivo.

Palabras clave: retorno, reconocimiento y eficacia extraterritorial del divorcio extrajudicial, liquidación del régimen económico del matrimonio, eficacia de las decisiones sobre alimentos y menores.

Abstract: The aim of this paper is to analyse the system of recognition of foreign extra-judicial divorces in Spain, considering as such those involving a non-judicial authority with a constitutive or merely federal character, as well as those based on a simple agreement between the spouses. The quantitative importance that they are acquiring in recent times shows the interest of the subject and the need for a detailed treatment of it in the absence of doctrinal studies on the subject. This is a complex issue, especially since diversity is the dominant factor in comparative law, and the decision or document dissolving the marriage may include pronouncements that differ from the mere constitution.

Keywords: return, recognition and extraterritorial effectiveness of extra-judicial divorce, dissolution of the bond, liquidation of the economic regime of the marriage, effectiveness of decisions on maintenance and minors.
\end{abstract}

Sumario: I. Introducción. II. Concepto y configuración legal del divorcio extrajudicial en Derecho comparado. 1. Una aproximación conceptual. 2. El divorcio extrajudicial en Derecho comparado. A) Iberoamérica. B) Europa. a' Europa nórdica. b' Europa oriental y central. c' Europa occidental y meridional. C) Asia y África. 3. Conclusiones. III. Condicionantes de la eficacia del divorcio extrajudicial extranjero en España. IV. Efecto constitutivo. 1. Régimen de reconocimiento en España

*Este trabajo se ha realizado en el marco del Proyecto de $\mathrm{I}+\mathrm{D}+\mathrm{i}$ "Retos de la regulación jurídico-patrimonial del matrimonio y de otras realidades (uniones de hecho) en los planos supraestatal y estatal (REJURPAT)" PID2019-106496RB-I00, del Programas estatal "Retos de la sociedad" y del Proyecto I+D "Instrumentación normativa de la política de retorno de emigrantes españoles y la atracción de talento global” (Referencia: RTI2018-099274-B-I00), financiado por: FEDER / Ministerio de Ciencia e Innovación - Agencia Estatal de Investigación. Todos los enlaces han sido consultados el 14/12/2020. 
del divorcio otorgado por autoridad extrajudicial extranjera. A) Derecho institucional. B) Derecho convencional. C) Derecho autónomo. 2. El régimen de reconocimiento de los "divorcios privados" extranjeros en España. A) ¿Pueden ser los divorcios pronunciados por tribunales religiosos extranjeros reconocidos en España? B) ¿Puede el divorcio contractual francés ser reconocido en España? V. Efectos de las cuestiones accesorias a la disolución del matrimonio.1. Liquidación del régimen económico matrimonial. 2. Obligaciones alimenticias. 3. Relaciones paterno-filiales. VI. Conclusiones.

\section{Introducción}

1. La experiencia migratoria supone un aprendizaje personal y profesional, optar por ella debe ser una decisión voluntaria y no forzada por las circunstancias. Durante la crisis económica, cientos de miles de españoles emigraron en busca de una oportunidad para ganarse la vida en otro país. La gran mayoría eran jóvenes bien formados, cuyas perspectivas laborales en España se limitaban al desempleo o la precariedad. Muchos de estos españoles que emigraron en su día por razones económicas desean retornar a España. De hecho, la política pública española se ha centrado en los últimos tiempos en facilitar su retorno a nuestro país ${ }^{1}$. Los beneficios económicos, familiares y sociales para España son evidentes. No obstante, son muchas las dificultades que se plantean en este contexto ${ }^{2}$, sobre todo, cuando los emigrados que desean retornar a España - al igual que les sucede a los ciudadanos extranjeros que emigran a nuestro paísnecesitan reconocer en nuestro país aquellas instituciones jurídico-familiares válidamente constituidas en otro Estado, y cuyo reconocimiento es preciso para regularizar su "status" personal en nuestro país.

Es relativamente frecuente en los tiempos en los que vivimos que la disolución de un matrimonio contraído en un Estado se produzca en otro. Para que esta surta efectos en nuestro país, es preciso que sea reconocida por parte de las autoridades españolas. El reconocimiento de un divorcio otorgado en el extranjero, en particular, de aquellos pronunciados por una autoridad no judicial extranjera, como los "divorcios privados", es decir, los obtenidos sin la intervención de la correspondiente autoridad -o con una intervención mínima-, resulta una tarea ardua y compleja.

2. Cada día hay más Estados que, ante la necesidad de descargar de trabajo a los órganos jurisdiccionales y agilizar los trámites, atribuyen facultades o competencias a autoridades no judiciales para disolver un matrimonio, como así ocurrió en España al admitir la competencia de los notarios para disolver un matrimonio ${ }^{3}$, así como en otros países de Iberoamérica (Cuba, México, Brasil, Colombia, Ecuador, Costa Rica, Perú, Bolivia y Nicaragua), de Europa (Portugal, Italia, Dinamarca, Noruega, Rusia, Letonia, Estonia, Ucrania, Moldavia y Rumania), de Asia (Japón, Kirguistán y China) y transcontinentales, como Armenia. Por otra parte, hay Estados en los que el divorcio se produce sin intervención de autoridad pública alguna o con una intervención muy limitada, como así sucede en Francia (art. 229$1^{\circ}$ Código civil francés ${ }^{4}$ y en los sistemas jurídicos de inspiración islámica ${ }^{5}$.

${ }^{1}$ El Gobierno español aprobó, el 22 de marzo de 2019, el Plan de retorno de emigrantes a España con el objetivo de fomentar el regreso de españoles al país en las mejores condiciones y facilitar su proceso de vuelta (https://www.sepe.es/ HomeSepe/Personas/plan-retorno-espana.html).

${ }^{2}$ A tales efectos, se publicó la Guía de retorno elaborada por el Ministerio de Trabajo y economía social (https://www.sepe. es/HomeSepe/Personas/plan-retorno-espana.html).

${ }^{3}$ Fue la Ley 15/2015, de 2 de julio, de Jurisdicción Voluntaria -en adelante LJV- (BOE de 3 de julio de 2015) la que confirió a tales autoridades dichas potestades. Al respecto, vid. J. Messía de la Cerda Ballestero, "La implantación del divorcio por mutuo acuerdo ante notario en España", Revista Crítica de Derecho Inmobiliario, nº 732, 2012, pp. 137-166.

${ }^{4}$ En Francia, el divorcio por mutuo acuerdo ha pasado a ser, desde que se aprobara la Ley núm. 2016-1547 de 18 noviembre de 2016 de Modernisation de la Justice du XXIe Siècle (JORF núm. 0269 du 19 novembre du 2016 en https://www.legifrance. gouv.fr/eli/loi/2016/11/18/JUSX1515639L/jo-), que modificó el Código civil francés, un asunto "privado" en el que es el acuerdo de los cónyuges el que produce el divorcio. No existe intervención de una autoridad pública para pronunciarlo. El papel que desempeña el notario en este divorcio sin juez es mínimo (C. Blanchard, "La fonction du notaire dans le divorce déjudiciarisé", La Semaine Juridique Notariale et Immobilière, no. 1, 6 janvier 2017, p. 1002; M. PereÑa Vicente, "El divorcio sin juez en el Derecho español y francés: entre el divorcio por notario y el divorcio por abogado. Dificultades teóricas y prácticas”, $A D C$, t. LXXII, fasc. I, 2019, pp. 5-52).

5 J. CARrascosa GonzÁlez, "Divorcio internacional y actividad notarial”, Familia y sucesiones: Cuaderno jurídico, nº 124, 2018, pp. 15-16. 
3. La importancia cuantitativa que está adquiriendo en los últimos tiempos la disolución del matrimonio vía extrajudicial evidencia el interés del tema y la necesidad de proceder a un tratamiento detenido y pormenorizado del mismo. En el presente trabajo abordaremos los problemas que su reconocimiento o eficacia plantean en España. Una cuestión que resulta compleja. No solo porque este tipo de divorcios pueden producirse sin intervención -o con una intervención mínima- de una autoridad, pública, sino por la diversidad que existe en este ámbito en Derecho comparado, lo que complica considerablemente, como veremos, la posibilidad de obtener el reconocimiento de tales divorcios en nuestro país. A ello hay que sumar que, toda decisión o documento en cuya virtud una autoridad extrajudicial extranjera disuelve un matrimonio puede incluir o no pronunciamientos diferentes al de la disolución del vínculo. Puede pronunciarse además sobre la liquidación del régimen económico del matrimonio, las obligaciones alimenticias, así como las relaciones paterno-filiales, lo que dificulta la cuestión de saber cómo será reconocido dicho divorcio en España. No obstante, antes de analizar cómo se reconocen estos tipos de divorcios en España, procederemos a formular un concepto aproximado y omnicomprensivo de divorcio extrajudicial capaz de abarcar la diversidad existente, así como a realizar un análisis de Derecho comparado, lo que nos permitirá revelar las similitudes y diferencias existentes en su configuración jurídica en los distintos Estado, así como constatar y comprender, en última instancia, la razón por la que el reconocimiento de un divorcio extrajudicial extranjero en nuestro país se revela una cuestión compleja.

\section{Concepto y configuración legal del divorcio extrajudicial en Derecho comparado}

\section{Una aproximación conceptual}

4. La dificultad de hallar un término adecuado capaz de abarcar todos los supuestos en los que puede disolverse un matrimonio sin intervención de una autoridad judicial permite advertir ab initio el complejo y diverso panorama que presenta en este ámbito el Derecho comparado. A fines del presente trabajo, hemos optado por emplear el término "divorcio extrajudicial", que resulta en cierto modo gráfico y omnicomprensivo de la diversidad existente en Derecho comparado.

Así pues, por divorcio extrajudicial debe entenderse tanto el que es dictado por una autoridad no judicial (notario, Encargado del Registro civil, etc.) en el que interviene con carácter constitutivo como los denominados "divorcios privados", basados en un mero acuerdo o pacto entre los cónyuges (divorcio privado francés), y los dictados por tribunales religiosos ( $a d e x$. Siria), en los que no interviene autoridad alguna o lo hace como mera federataria. Quedan excluidos de esta definición, por tanto, aquellos divorcios que tienen lugar tras la solicitud unilateral de las partes y en los que la autoridad pública interviene controlando su legalidad, como así ocurre con el talaq marroquí, puesto que, desde que se reformó el Código de Familia Marroquí (Al Mudawana), para poder disolver el vínculo matrimonial por talaq es preciso la apertura de un procedimiento judicial7 ${ }^{7}$. No cabe, por tanto, calificar a estos tipos de divorcios de "privados".

\section{EI divorcio extrajudicial en Derecho comparado}

5. Actualmente son numerosos los Estados que reconocen la posibilidad de disolver extrajudicialmente el matrimonio tanto en el continente americano como en el europeo y el asiático.

\footnotetext{
${ }^{6}$ A.L. Calvo Caravaca/ J. Carrascosa GonzÁlez, Derecho internacional privado, vol. II, Granada, Comares, 2018, p. 255.

${ }^{7}$ N. Marchal Escalona, "Nulidad, separación y divorcio de la mujer marroquí en España", en C. RUiz sutil, R. RUEDA valdivia (Coords.), La situación jurídico-familiar de la mujer marroquí en España, Sevilla, Junta de Andalucía, Instituto andaluz de la Mujer, 2008, pp. 219-244; Ma . Ortiz VIDAL, "El repudio en el código de familia de marruecos y la aplicación del Derecho marroquí en la UE", $C D T, 2014$, vol. 6, n² 2, pp. 201-244.
} 


\section{A) Iberoamérica}

6. La disolución notarial del matrimonio constituye una práctica muy habitual en estos países. Cuba fue pionero en admitir el divorcio por mutuo acuerdo ante notario. Según el Decreto-Ley no 154/1994 de 6 de septiembre, este procederá “cuando exista mutuo acuerdo entre los cónyuges sobre la disolución del vínculo matrimonial y sus efectos inmediatos y no se emita por el Fiscal dictamen en contrario, en su caso" $\left(\right.$ art. $\left.^{8}\right)$. A falta del acuerdo, el divorcio se tramitará por la vía judicial. A tales efectos, los cónyuges deben solicitar conjuntamente, por si o por representación, la disolución del vínculo matrimonial (art. 2). La tramitación del divorcio se regirá por los principios y normas del Código de la Familia ante notario y lo establecido en la Ley de las notarías Estatales y su reglamento (art. 3) ${ }^{9}$. El notario tiene la obligación de verificar la legalidad de los acuerdos alcanzados por los cónyuges y en especial lo relativo a las relaciones paterno filiales, patria potestad, guarda y custodia de los hijos comunes ${ }^{10}$. Asimismo, deberá dar traslado de la solicitud del divorcio al Fiscal cuando, a su juicio, los acuerdos de los cónyuges sean lesivos o cuando pretendan deferir la patria potestad sobre los hijos comunes a favor de uno solo de los padres. El Fiscal, al recibir una solicitud de divorcio, analizará la procedencia o no de los acuerdos en relación con los intereses de los menores y emitirá un dictamen al respecto que enviará al notario encargado de tramitar la solicitud de disolución del vínculo matrimonia ${ }^{11}$. Si dicha autoridad emite dictamen contrario a alguno de los acuerdos propuestos por los cónyuges, el notario lo hará saber a los interesados por si, en atención a lo señalado por el Fiscal, aceptan su modificación. Si los cónyuges aceptan modificar sus acuerdos, según lo señalado por el Fiscal, el notario continuará la tramitación del divorcio. En caso contrario, interrumpirá su sustanciación dejando expedita la vía judicial informando de ello a los interesados (art. 8).

7. El art. 272 del Código Civil Federal mexicano admite la disolución del matrimonio ante el Juez del Registro Civil. Para ello, ambos cónyuges deben convenir de mutuo acuerdo en divorciarse, ser mayores de edad, no tener hijos y haber liquidado de común acuerdo la sociedad conyugal ${ }^{12}$. En tales casos, el Juez del Registro Civil, previa identificación de los cónyuges, levantará acta en la que hará constar la solicitud de divorcio y citará a los cónyuges para que se presenten a ratificarla a los quince días. Si los consortes se ratifican, el Juez del Registro Civil los declarará divorciados, levantando el acta respectiva y haciendo la anotación correspondiente en la del matrimonio anterior. El divorcio no surtirá efectos legales si se comprueba que los cónyuges tienen hijos menores de edad o no han liquidado la sociedad conyugal. Con todo, México es un sistema plurilegislativo ${ }^{13}$, y hay Estados en los que se admite

\footnotetext{
${ }^{8}$ Disponible en http://juriscuba.com/wp-content/uploads/2015/10/Decreto-Ley-No.-154.pdf). Para un análisis del mismo, vid. J.L. Ordelin Font, "Dos décadas de divorcio notarial en Cuba: ¿hacia dónde vamos", 20144, pp. 1-28 en http://www. notariado.org/liferay/c/document_library/get_file?folderId=13807670\&name=DLFE-222967.pdf.

La escritura notarial que declare el divorcio tendrá, según el art. 9, fuerza ejecutiva directa e inmediata, a todos los efectos legales y contendrá los acuerdos de los cónyuges sobre los aspectos siguientes: "a) la disolución del vínculo matrimonial, b) la determinación en relación con la conservación de la patria potestad sobre los hijos comunes menores, salvo que existiese fallo judicial en contrario, acreditado por alguno de los cónyuges, c) el discernimiento de la guarda y cuidado de los hijos comunes menores d) la determinación de la cuantía de la pensión, que corresponda conceder a los hijos comunes menores y al ex cónyuge, en su caso, e) el régimen de comunicación de aquel de los padres al que no se le confiere la guarda y cuidado de los hijos comunes menores con estos, $f$ ) las convenciones de los cónyuges sobre el destino de la vivienda, si procediere, $g$ ) las advertencias legales correspondientes en cuanto a la liquidación de la comunidad matrimonial de bienes, en caso de que expresamente declinaran su derecho a realizarla en el propio acto".

${ }^{10}$ En concreto, velará, según lo dispuesto en el art. 4, que tal convenio no atente contra: “a) el normal desarrollo y cuidado de los hijos comunes menores b) la adecuada interrelación y comunicación entre padres e hijos c) la satisfacción de las necesidades económicas de los hijos comunes menores d) la salvaguarda de los interesares de los hijos comunes menores y e) el cumplimiento de los deberes que corresponden a los padres".

${ }^{11}$ Toda modificación sobre las relaciones paterno filiales referidas a la patria potestad, guarda y cuidado de los hijos comunes menores, régimen de comunicación o pensiones que surjan con posterioridad a la fecha de la escritura de divorcio, se resolverán ante notario, siempre que no exista contradicción entre los ex cónyuges (art. 11). El incumplimiento de cualquiera de los ex cónyuges de algunos de sus pronunciamientos contenidos en la escritura del divorcio, se resolverá en proceso de ejecución ante el tribunal municipal popular correspondiente (art. 12).

${ }^{12} \mathrm{https} / /$ mexico.justia.com/federales/codigos/codigo-civil-federal/libro-primero/titulo-quinto/capitulo-x/.

${ }^{13}$ I. Soto Sobreyra y Silva, "Matrimonio y divorcio en sede notarial", Revista de la Facultad de Derecho de México, 264, 2015, pp. 120-142.
} 
igualmente la posibilidad de que los cónyuges obtengan su divorcio vía notarial, como así sucede en el Estado de México ${ }^{14}$, de Jalisco ${ }^{15}$ y de Puebla ${ }^{16}$.

8. En Brasil se permite, en virtud de lo establecido en la Ley n ${ }^{\circ}$ 11411/2007 de 4 de enero -implementada por la Resolución núm. 35 de 24 de abril del 2007 del Consejo Nacional de Justicia ${ }^{17}$-, el divorcio notaria $~^{18}$. Los cónyuges podrán divorciarse vía notarial, siempre que no haya hijos menores de edad o incapaces y exista acuerdo sobre el reparto de los bienes comunes, la pensión alimenticia y la recuperación del nombre de soltero o mantenimiento del de casado. También se exige que los esposos estén separados de hecho durante, al menos, el plazo de dos años ${ }^{19}$.

9. En Colombia, el art. 34 de la Ley ${ }^{0} 962 / 2005$ de 8 de julio ${ }^{20}$-implementado con posterioridad por el Decreto $\mathrm{n}^{\circ} 4436$ de 28 de noviembre del 2005 del Ministerio de Justicia e Interior de Colombia ${ }^{21}$ - introdujo la posibilidad de obtener el divorcio ante notario. Este podrá convenirse por mutuo acuerdo de los cónyuges, con intermediación de abogado, mediante escritura pública con los mismos efectos que el decretado judicialmente ${ }^{22}$. La intervención del "Defensor de familia" es obligatoria en el caso de que existan hijos menores de edad, y su dictamen es vinculante tanto para el notario como para los cónyuges, quienes deben modificar su convenio para adaptarlo, pues, de lo contrario, el divorcio deberá de ser judicial. Como en la legislación cubana, para sustentar la petición deben acompañar los certificados de matrimonio y de nacimiento de los hijos menores de edad, así como el poder conferido para la representación de uno de los cónyuges, con facultad expresa para suscribir la escritura pública de divorcio, de darse el supuesto. Si los cónyuges no comparecen a ratificarlo, transcurridos dos meses desde que fue puesto a disposición, se entenderá que desisten de su petición.

10. El legislador ecuatoriano admitió el divorcio notarial en virtud de la Ley $n^{0} 2006-62^{23}$. A partir de dicha fecha, los notarios ecuatorianos pueden tramitar el divorcio por mutuo consentimiento,

${ }^{14}$ Será factible siempre que sea de común acuerdo, no haya hijos menores de edad o discapacitados que dependan de ambos y no existan deudas en común en http://derechomexicano.com.mx/notarios-en-mexico-podran-divorciar.

${ }^{15}$ Dicha posibilidad fue introducida por el Decreto 26926/LXI/18 (art. 775 bis) en https://periodicooficial.jalisco.gob.mx/ content/sabado-1-de-septiembre-de-2018-2.

${ }^{16}$ En particular, quienes soliciten el divorcio administrativo deberán estar sometidos al régimen de separación de bienes o presentar convenio de liquidación, tener al menos un año de casados y no tener hijos menores de edad o discapacitados (art. 436 III y VI del Código civil del Estado de Puebla). A tales efectos, los cónyuges se presentarán personalmente al notario de su elección (art. 437 Código civil del Estado de Puebla) en https:/www.milenio.com/opinion/varios-autores/escuela-libre-dederecho-de-puebla/el-divorcio-ante-notario-en-el-estado-de-puebla.

${ }^{17} \mathrm{http}: / /$ www.lex.com.br/doc_3859022_RESOLUCAO_N_35_DE_24_DE_ABRIL_DE_2007.aspx.

18 "A separação consensual e o divórcio consensual, não havendo filhos menores ou incapazes do casal e observados os requisitos legais quanto aos prazos, poderão ser realizados por escritura pública, da qual constarão as disposições relativas à descrição e à partilha dos bens comuns e à pensão alimentícia e, ainda, ao acordo quanto à retomada pelo cônjuge de seu nome de solteiro ou à manutenção do nome adotado quando se deu o casamento. $1^{\circ}$ A escritura não depende de homologação judicial e constitui título hábil para o registro civil e o registro de imóveis. $2^{\circ} \mathrm{O}$ tabelião somente lavrará a escritura se os contratantes estiverem assistidos por advogado comum ou advogados de cada um deles, cuja qualificação e assinatura constarão do ato notarial". A escritura e demais atos notariais serão gratuitos àqueles que se declararem pobres sob as penas da lei" en http://www.planalto.gov.br/ccivil_03/_ato2007-2010/2007/lei/111441.htm. Para un análisis del mismo, vid. T. Vainsencher, "El divorcio en el Derecho brasileño", en A. Acedo Penco, L.B. Pérez gallardo (Coords.), El divorcio en el Derecho Iberoamericano, Bogotá, México D.F., Madrid, Buenos Aires, Temis, Ubijus, Reus, Zavalia, 2009, pp. 123-145.

${ }^{19} \mathrm{Si}$ existe sentencia de separación judicial, basta el transcurso de un año. Todo debe ser acreditado documentalmente por medio de los oportunos certificados registrales (matrimonio e hijos) y el convenio de liquidación de bienes comunes [E.Ma . RODRÍGUEZ DÍAz, "El divorcio notarial en España (perspectiva en Derecho Comparado y problemática de la actual regulación)", Revista Jurídica de Asturias, nº 41, 2018, pp. 32-33 en https://www.unioviedo.es/reunido/index.php/RJA/article/view/]

${ }^{20}$ DO núm. 45.963 de 8 de julio de 2005.

${ }^{21} \mathrm{https}: / /$ www.funcionpublica.gov.co/eva/gestornormativo/norma.php?i=18346.

${ }^{22}$ La solicitud deberá contener disposiciones sobre el cumplimiento de las obligaciones de alimentos entre los cónyuges, si es el caso, el estado en que se encuentra la sociedad conyugal e información sobre la existencia o no de hijos menores de edad. De existir, el acuerdo debe comprender además el convenio sobre la pensión de alimentos, la custodia, el régimen de visitas y la periodicidad de las mismas (art. 2).

${ }^{23} \mathrm{https} / /$ www.asobanca.org.ec/sites/default/files/Ley\%20Reformatoria\%20de\%201a\%20Ley\%20Notarial.pdf. 
siempre que no haya hijos menores de edad o bajo su dependencia. Los cónyuges deberán estar asesorados por un abogado y ratificar su voluntad de divorciarse en una audiencia que se fijará dentro de un plazo no mayor a diez días. Estos pueden comparecer personalmente o estar representados. A petición de las partes y de mutuo consentimiento, el notario en el mismo acto procederá a la liquidación de sociedad de bienes o de la sociedad conyugal.

11. La Ley n ${ }^{\circ} 29227 / 2008$ de 16 de mayo-implementada por el Decreto Supremo 009-2008-J.U.S. del 12 de junio del $2008^{24}$ - regula el procedimiento de separación convencional y de ulterior divorcio en las municipalidades y notarías en Perú, así como ante el alcalde ${ }^{25}$. Podrán acogerse a dicha Ley los cónyuges que, después de transcurridos dos años de la celebración del matrimonio, decidan solicitar su separación convencional y ulterior divorcio (art. 2). Los requisitos que deberán cumplir para obtener dicho divorcio son: no tener hijos menores de edad, carecer de bienes sujetos al régimen de sociedad de gananciales o contar con escritura pública de liquidación del régimen patrimonial. Presentada la solicitud con los requisitos correspondientes, el notario o alcalde verificará los documentos y convocará a los cónyuges a una audiencia única en un plazo de 15 días (art. 10). En la comparecencia, los cónyuges ratificarán su solicitud de separación (art. 12). La Ley permite a las partes poder concurrir a dicha audiencia a través de sus representantes con poder debidamente inscrito ante los Registros Públicos. Transcurridos dos meses de la declaración de la separación convencional, cualquiera de los esposos podrá solicitar al notario la disolución del matrimonio (art.13). La solicitud será resuelta dentro de los quince días siguientes.

12. El art. 206 del Código de las Familias y del Proceso Familiar, aprobado por Ley ${ }^{0} 603$, de 19 de noviembre de 2014, introdujo en Bolivia la posibilidad de obtener el divorcio administrativo de mutuo acuerdo por vía notaria ${ }^{26}$. Se exige el consentimiento de ambos cónyuges, no existir hijos o, de haberlos, que sean mayores de 25 años, que no tengan bienes gananciales y no exista pretensión de asistencia familiar por ninguno de los cónyuges (art. 95 Ley del Notariado plurinacional de 25 de enero de $2014^{27}$ ). Los cónyuges, en el término de tres meses, deberán presentarse nuevamente ante el notario para ratificar su petición, que será protocolizada. Si transcurren seis meses sin que ambos cónyuges se presenten a ratificar su propósito de divorciarse, el trámite se considera caducado y será archivado (art. 95 Ley del Notariado).

13. El art. 159 de la Ley $n^{\circ}$. 870 , aprobada el 24 de junio de $2014^{28}$, prevé la posibilidad de obtener en Nicaragua el divorcio de mutuo acuerdo ante notario ${ }^{29}$. Para ello, es preciso que no existan hijos comunes menores o personas con discapacidad, ni bienes en común. En el caso de que existan, se requiere un acuerdo sobre la forma de uso o distribución de los mismos. El notario podrá disolver el vínculo matrimonial, debiendo consignar el pacto en la escritura pública correspondiente ${ }^{30}$. El notario, al recibir la petición de disolución por mutuo consentimiento, advertirá a los cónyuges el efecto de su decisión (art. 160). El testimonio de la escritura de disolución del vínculo matrimonial por mutuo consentimiento, que libre el notario, se inscribirá en el Registro del Estado Civil de las Personas y en el Registro Público de la Propiedad, cuando corresponda (art. 162) ${ }^{31}$.

\footnotetext{
${ }^{24}$ http://www.municallao.gob.pe/contenidosMPC/transparencia/pdf/documentos/Ley-Nro29227.pdf. Al respecto, vid. C.J. Cabello Matamala, "El divorcio en el Derecho peruano", en A. Acedo Penco/ L.B. Pérez Gallardo (Coords.), El divorcio en el Derecho Iberoamericano, Madrid, Temis, 2009, pp. 525-550.

${ }^{25} \mathrm{https}$ //www.derechoecuador.com/registro-oficial/2006/11/registro-oficial-28-de-noviembre-del-2006.

${ }^{26} \mathrm{https}: / /$ www.derechoteca.com/gacetabolivia/ley-no-603-del-19-de-noviembre-de-2014.

${ }^{27} \mathrm{https} / / /$ www.lexivox.org/norms/BO-L-N483.html.

${ }^{28} \mathrm{http}: / /$ extwprlegs1.fao.org/docs/pdf/nic138841.pdf.

${ }^{29} \mathrm{Vid}$. L.B. Pérez Gallardo "Divorcio por mutuo consentimiento ante notario en el nuevo Código de Familia de Nicaragua: la fábula de la zorra y el cangrejo de mar", Anuario de la Facultad de Derecho, vol. XXXI, 2014, pp. 429-457.

${ }^{30} \mathrm{El}$ art. 161 dispone la documentación que los esposos deben aportar con la solicitud de divorcio ante notario, entre los que destaca la "certificación negativa de hijos e hijas y de bienes".

${ }^{31}$ E.Ma'. Rodríguez Díaz, "El divorcio notarial...”, loc.cit, pp. 87-88.
} 
14. En suma, el análisis de la normativa vigente en los diferentes países iberoamericanos que admiten este tipo de divorcio evidencia que, aunque son diversas las autoridades no judiciales con competencia para otorgar el divorcio -notario, alcalde o Juez encargado del Registro civil-, existe preferencia por el divorcio notarial, siempre que no haya hijos menores de edad, salvo en Cuba y Colombia. A partir de aquí, las diferencias se multiplican. Hay Estados donde la liquidación de la sociedad conyugal es un requisito esencial para poder acordar el divorcio ( $a d$ ex. Perú y México); mientras que, en otros ordenamientos, como así sucede en Ecuador, Colombia y Brasil, la liquidación del régimen económico del matrimonio puede hacerse simultáneamente o con posterioridad al divorcio. Esta puede constar en la misma escritura pública o en otra diferente, como así sucede en Ecuador. De la misma manera, no existe unanimidad en torno a si es precisa (o no) la intervención del abogado en la tramitación del divorcio, así como también si cabe (o no) la representación de las partes. Esta diversidad es igualmente patente en otros extremos, como, por ejemplo, la documentación que debe ser presentada al solicitar el divorcio; la necesidad de obtener previamente la separación convencional, como así sucede en Perú, así como si los cónyuges tienen que asistir (o no) a una audiencia para ratificarse ${ }^{32}$.

\section{B) Europa}

a) Europa nórdica

15. El divorcio extrajudicial se admite tanto en Noruega como en Dinamarca. En Noruega, según lo establecido en la Sec. 16 a) y 19-26 de la The Marriage Act, los trámites de separación y divorcio pueden realizarse ante la Oficina del Fylkesmann (Gobernador del Condado) del último domicilio del matrimonio que desea separarse o divorciarse. Si ninguno de los cónyuges vive allí, podrá instarse ante el Gobernador de cualquiera de los domicilios al tiempo de la petición ${ }^{33}$. De existir hijos menores de 16 años, la petición irá acompañada de un certificado de mediación acordado dentro de los seis meses anteriores a la solicitud (Sec. 26). Una vez tramitado el decreto de separación, se enviará a los interesados. Transcurrido un año desde la fecha del decreto de separación, se podrá solicitar el divorcio (Sec. 21), de forma que, si solo uno de los cónyuges desea divorciarse, podrá hacerlo, pese a la objeción de la otra. Si ambos están de acuerdo, su petición de divorcio será procesada por el Gobernador del Condado, salvo que no exista acuerdo sobre los términos del mismo. En tal caso, el divorcio tendrá que ser pronunciado por los tribunales (Sec. 27).

16. En Dinamarca, la separación y el divorcio se puede obtener por decreto administrativo o bevilling (Sec. $42.1^{\circ}$ de la Danish Marriage Act Section ${ }^{34}$ ) con los mismos efectos jurídicos que cuando media sentencia judicial (Sec. 42). No obstante, la posibilidad de obtener el divorcio por decreto administrativo solo será posible si los cónyuges, de común acuerdo, desean que se decrete la separación o divorcio por vía administrativa y están conformes respecto a los aspectos relativos a la patria potestad, la custodia de los hijos menores, la obligación de alimentos entre cónyuges, etc. (Sec. $42.2^{\circ}$ ). Los decretos administrativos son extendidos por el Ministerio de Justicia o por el Departamento (statsamt ${ }^{35}$ ) correspondiente, mediante delegación del Ministro de Justicia [Sec. 42 a) $1^{\circ}$ ].

En suma, el divorcio se puede obtener en tales países ante autoridades administrativas pudiendo decretarse, incluso, cuando hay hijos menores de edad.

\footnotetext{
${ }^{32}$ Para un análisis más pormenorizado de tales diferencias, vid. D. Leonardo/ B. Pérez Gallardo, "Un «fantasma» recorre Latinoamérica en los albores de este siglo: el divorcio por mutuo acuerdo en sede notarial”, pp. 1-43 en http://Dialnet/ UnFantasmaRecorreLatinoamericaEnLosAlboresDeEsteSi-3233237\%20(6).pdf.

${ }^{33} \mathrm{https}$ ://www.regjeringen.no/contentassets/165b14b004784e9c86944f2e2301ce85/helt-endelig-versjon-ekteskapslovenengelsk-oppdat.-februar-2018-revidert-mht-kommentarer-fra-bld-og-jd-innarbeidet.pdf

${ }^{34} \mathrm{http}$ //host.uniroma3.it/progetti/cedir/cedir/Lex-doc/Dk_marrig.pdf.

${ }^{35}$ El statsamt es el órgano administrativo superior de cada una de las catorce regiones en las que se divide Dinamarca a efectos administrativos. Tiene competencia en algunos asuntos de Derecho de familia y personas (E.Ma .RodríGUEz Díaz, "El divorcio notarial...", loc.cit, p. 78).
} 
b) Europa oriental y central

17. Son varios los países europeos que admiten este tipo de divorcio ${ }^{36}$. El art. 69 del Código civil de Letonia, tras la reforma habida en dicho Estado en 2010, admite que el matrimonio sea disuelto por un tribunal judicial o por un notario/notārs ${ }^{37}$. El notario podrá disolver el matrimonio previo acuerdo de los cónyuges, si no tienen hijos menores en común ni bienes compartidos (art. 69.3 $3^{\circ}$.

18. En Rumanía, el art. 375 del Código civil rumano reconoce que el divorcio por acuerdo de los cónyuges puede tramitarse, bien por vía administrativa ante el responsable del Registro Civil, o bien ante notario del lugar donde se celebró el matrimonio o de la última residencia en común de los cónyuges. Si no tienen hijos menores, nacidos dentro o fuera del matrimonio o adoptados, el notario podrá decretar el divorcio. Si los hay, solo podrá hacerlo si los cónyuges pactan sobre el apellido a llevar tras el mismo, el ejercicio de la patria potestad por ambos padres, la fijación del domicilio de los hijos tras el divorcio, las relaciones personales entre los padres y cada uno de los hijos, la contribución a los gastos de cuidado, educación, enseñanza y formación profesional de los hijos, etc. ${ }^{38}$. La solicitud de divorcio se presentará por los dos cónyuges, bien personalmente o bien por medio de un representante con poder notarial. El notario les concederá un plazo de reflexión de treinta días, tras el cual, los cónyuges se presentarán personalmente. Este verificará si los cónyuges persisten en deseo de divorciarse y si el consentimiento es libre (o no). El notario expedirá el certificado de divorcio, remitirá una copia certificada del mismo al Ayuntamiento del lugar de celebración del matrimonio. Si desestima la petición, los cónyuges tienen abierta la vía judicial ${ }^{39}$.

19. En Estonia, según la Family Law Act de 18 de noviembre de $2009^{40}$ y la Vital Statistics Registration Act de 20 de mayo de $2009^{41}$, el divorcio puede obtenerse ante la Oficina del Registro Civil o ante notario del lugar de residencia de cualquiera de los cónyuges, previo acuerdo de las partes, siempre que ambos cónyuges residan en Estonia con independencia de que haya o no hijos menores o discapacitados. Para obtener el divorcio, se requiere la presentación de una la solicitud personal y conjunta por escrito, realizada por los cónyuges, a la que han de acompañar el certificado del matrimonio y la confirmación de carecer de conflictos en relación con los menores, con la división del patrimonio común o con las resoluciones en materia de alimentos. Si un cónyuge no puede comparecer personalmente por razones justificadas ante la Oficina del Registro Civil para poder entregar la solicitud conjunta, podrá entregar una solicitud por separado siempre que haya sido certificada por un notario.

20. En Rusia, el art. 18 del Family Code admite el divorcio de mutuo acuerdo ante el Registry Offices $^{42}$, siempre que no haya hijos menores ${ }^{43}$. No obstante, en determinados supuestos, es factible disolver el matrimonio ante dicha autoridad a solicitud de uno solo de los cónyuges, con independencia de que existan o no hijos menores de edad comunes (art. 1944). Dicha autoridad no se pronunciará sobre

\footnotetext{
${ }^{36}$ Por el contrario, en otros países, como así sucediera en Lituania y en Bielorrusia, se abolió en el S. XX el divorcio administrativo [M. ANTOKolskoia, "European Family Law", en J.M. Cherpe (Ed.), Family Law in a European Perspectivein, Vol. III, Masachuses, E. Elgar Publishing, 2016, p. 75].

${ }^{37}$ Según el cual: "A notary may dissolve a marriage in accordance with the procedures laid down in the Notariate Law if both spouses agree on the divorce. A marriage is dissolved as of the day when a notary has drawn up a divorce certificate" en http://www.vvc.gov.lv/export/sites/default/docs/LRTA/Likumi/The_Civil_Law.doc.

${ }^{38}$ El notario recabará un "informe de investigación social" para verificar que el acuerdo de los cónyuges respecto al ejercicio común de la patria potestad o el relativo a la fijación del domicilio de los hijos es beneficioso para estos, pues, en caso contrario, no podrá disolver el matrimonio y quedará abierta la vía judicial.

${ }^{39}$ E.M". RodríGuez DíAz, "El divorcio notarial...", loc.cit., pp. 87-88.

${ }^{40} \mathrm{https} / / /$ www.riigiteataja.ee/en/eli/530102013016/consolide.

${ }^{41} \mathrm{https} / / / w w w . r i i g i t e a t a j a . e e / e n / e l i / 504022014001 /$ consolide.

42 "The stateregistration of the dissolution of the marriage shall be effected by the registryoffices in conformity with the procedure established for the state registration of civil status acts" en http://www.jafbase.fr/docEstEurope/RussianFamilyCode1995.pdf.

43 "In case there is mutual consent to the dissolution of the marriage on the part of both spouses who have no underaged child, the marriage shall be dissolved at registry offices" en http://www.jafbase.fr/docEstEurope/RussianFamilyCode1995.pdf.

44 "Dissolution of the marriage upon an application of one of the spouses, regardless of whether the spouses have or have not common underaged children, shall be effected at registry offices, if the other spouse: is recognized by a court as missing; is
} 
las cuestiones que afectan al régimen económico del matrimonio o pensión compensatoria, que deberán de resolverse vía judicial ${ }^{45}$.

21. El art. 105 del Family Code de Ucrania prevé la disolución del matrimonio ante autoridad registral mediante la solicitud conjunta de los cónyuges si no existen hijos menores (art. 106), o a petición de uno de ellos, pero solo en determinados supuestos (art. 10746). El matrimonio se disuelve con independencia de las disputas de propiedad que pudieran existir entre los cónyuges (arts. 106.3 y 107.3 ${ }^{\circ}$.

22. El divorcio ante la autoridad registral es admitido igualmente en los arts. 35 y 36 del $\mathrm{Fa}$ mily Code de Moldavi $a^{47}$, siempre que exista acuerdo entre los cónyuges y no tengan hijos menores o adoptados (art. 36.1 ${ }^{148}$ ). No obstante, también puede disolverse a solicitud de uno de los cónyuges en las circunstancias que el art. $36.2^{\circ}$ establece. Si existe acuerdo entre ellos en cuanto a la división de la propiedad común del patrimonio, la manutención, educación y domicilio de los hijos menores comunes o la manutención de uno de los cónyuges, el matrimonio se podrá disolver ante dicha autoridad.

23. En este mismo sentido se pronuncia el art. 9 del Family Code de Armenia, un país transcontinental, donde el matrimonio es disuelto por el Civic Status Registration Departments, según el procedimiento establecido (arts. 9 y 14$)^{49}$, siempre que haya consentimiento mutuo de los cónyuges, o a instancia de una de las partes ex art. 15.2 ${ }^{050}$. Las disputas sobre las propiedades comunes de los cónyuges, así como sobre los hijos son resueltas vía judicial (art. 15.3 $\left.{ }^{\circ}\right)^{51}$.

c) Europa occidental y meridional

24. La Ley $61 / 2008$, de 31 de octubre, “Altera o regime jurídico do divórcio”, consolidó el divorcio de mutuo acuerdo ante el Encargado del Registro Civil (Conservatória do Registo Civil) en Portugal ${ }^{12}$. Para ello, se exige el acuerdo de los esposos sobre las consecuencias de la ruptura, incluso sobre el ejercicio de las responsabilidades parentales cuando existan hijos menores (art. 175 Código civil ${ }^{53}$ ). El encargado del Registro Civil convocará a los cónyuges a una comparecencia para verificar el cumplimiento de los

recognized by a court as legally incapable; is sentenced to imprisonment for committing a crime for a term of over three years. 3. Dissolution of the marriage and the issue of the certificate on the dissolution of the marriage shall be effected by the registry office upon the expiry of one month from the date of filing an application on the dissolution of the marriage".

45 "Disputes about dividing the spouses common property, about the payment of the means for the maintenance of a disabled needy spouse, and also disputes about children arising between the spouses, one of whom is recognized by the court as legally incapable or is sentenced for committing a crime to imprisonment for a term of over three years (Item 2, Article 19 of the present Code), shall be considered in court, apart from dissolution of the marriage at registry offices".

46 "1. The public civil status act registration authority dissolves the marriage upon application lodged by one of spouses if the other of spouses: 1) has been found missing, 2) has been found legally incapable, 3) has been sentenced to at least three years of jail for committing a crime" en http://jafbase.fr/docEstEurope/FAMILY_CODE_OF_UKRAINE.pdf.

${ }^{47} \mathrm{http}$ ://lex.justice.md/index.php?action=view\&view=doc\&lang=1\&id=286119.

48 "In baza acordului comúun al sotilor care nu au copii minori comuni sau infiati de ambii soti, in cazurile cind intre acestia un exista litigii referitoare la partaj sau la intretinerea sotului inapt de munca, casatoria poate fi desfacuta de catre oficiul de stare civila in a carui raza teritoriala se afla domiciliul unuia dintre soti, cuparticiparea obligatorie a ambilor soti".

${ }^{49} \mathrm{http}: / /$ www.parliament.am/law_docs/081204HO123eng.pdf

50 "On the basis of the application from one of the spouses the divorce is realized in the Civic Status Registration Department if the second spouse: a) is recognized missing by court; b) is recognized incapable by court; $c$ ) is convicted to imprisonment for the period of no less then 3 years".

51 "The disputes on the share of the common property of the spouses, on meeting the living expenses of an incapable vulnerable spouse, as well as the disputes on children are considered by judicial procedure irrespective of the marriage cancellation in the Registration Department in accordance with the procedure established by Article 17 of the given Code".

${ }^{52} \mathrm{http}: / /$ www.pgdlisboa.pt/leis/lei_mostra_articulado.php?nid=1028\&tabela=leis\&so_miolo.

53 " 1 - O divórcio por mútuo consentimento pode ser requerido pelos cônjuges a todo o tempo. 2. Os cônjuges não têm de revelar a causa do divórcio, mas devem acordar sobre a prestação de alimentos ao cônjuge que deles careça, o exercício do poder paternal relativamente aos filhos menores e o destino da casa de morada da família. 3. Os cônjuges devem acordar ainda sobre o regime que vigorará, no periodo da pendência do processo, quanto à prestação de alimentos, ao exercício do poder paternal e à utilização da casa de morada de familia" en https://www.cascais.pt/sites/default/files/anexos/gerais/ codigo_civil_atualizado_ate_a_lei_59_99_.pdf 
requisitos legales y acuerdos e invitará a las partes a modificarlos si, a su juicio, vulneran los intereses de alguna de los cónyuges o de los hijos. De estimarlos conformes, decretará el divorcio, que será inscrito y tendrá los mismos efectos que el divorcio judicial (art. 1.776.2 ${ }^{\circ}$ Código civil). En caso contrario, remitirá el asunto a los tribunales para su examen, si estima que lesionan los citados intereses (art. 1.778 Código civil). Cuando existan hijos menores, el Encargado del Registro Civil deberá remitir los acuerdos al Ministerio Fiscal del Tribunal de Primera Instancia competente para que informe en el plazo de treinta días. Si este no los estima beneficiosos para los intereses de los menores, las partes pueden modificarlos. En caso contrario, el divorcio se remitirá de oficio al Tribunal al que pertenezca la Conservaduría (art. 1.778 Código civil). Dicha norma fue implementada años más tarde por el Decreto-Lei $\mathrm{n}^{\mathrm{o}} 272 / 2001^{54}$ a partir del cual se procedió a transferir ciertas competencias en asuntos familiares a las Oficinas del Registro Civil (la asignación de alimentos a los hijos mayores y al hogar de la familia, la privación y autorización de apodos del cónyuge actual o anterior y la conversión de la separación en divorcio, etc.).

25. En Italia, la Legge $\mathrm{n}^{\mathrm{o}} 162$, de 10 de noviembre de 2014, de conversión en Ley del Decreto Legge $\mathrm{n}^{\circ}$ 132, de 12 de septiembre de 2014, instauró el divorcio administrativo ante el Ufficiale dello Stato Civile, con asistencia de abogado para los matrimonios sin hijos y sin patrimonio común que estén de acuerdo en divorciarse ${ }^{55}$.

26. En España, desde 2015, según lo dispuesto en el art. 87 Código civil, los cónyuges pueden acordar su divorcio de mutuo acuerdo mediante la formulación de un convenio regulador en escritura pública ante notario - territorial ${ }^{56}$ e internacionalmente ${ }^{57}$ - competente. Ahora bien, para que un notario pueda autorizar una escritura notarial de divorcio deberá existir mutuo acuerdo de los cónyuges y haber transcurrido, al menos, tres meses desde la celebración del matrimonio. No procederá si existen hijos menores no emancipados o con la capacidad modificada judicialmente que dependan de sus progenitores ${ }^{58}$.

Los requisitos para el otorgamiento de escritura pública de divorcio se regirán, cualquiera que sea la ley sustantiva aplicable al mismo, por la ley española (lex fori regit actum). En tales casos, resultará obligatorio presentar un acuerdo o "convenio regulador" que canalice de la voluntad de las partes (autonomía de la voluntad material), y en el que conste la voluntad inequívoca de los cónyuges en disolver el matri-

\footnotetext{
${ }^{54} \mathrm{https}: / /$ dre.pt/home/-/dre/621556/details/maximized

55 "I coniugi possono concludere, innanzi all'ufficiale dello stato civile del comune di residenza di uno di loro o del comune presso cui e' iscritto o trascritto l'atto di matrimonio, un accordo di separazione personale ovvero, nei casi di cui all'articolo 3 primo comma, numero 2), lettera b), della legge 10 dicembre 1970 n. 898, di scioglimento o di cessazione degli effetti civili del matrimonio, nonche' di modifica delle condizioni di separazione o di divorzio. 2. Le disposizioni di cui al presente articolo non si applicano in presenza di figli minori, di figli maggiorenni incapaci o portatori di handicap grave ovvero economicamente non autosufficienti. 3. L'ufficiale dello stato civile riceve da ciascuna delle parti personalmente la dichiarazione che esse vogliono separarsi ovvero far cessare gli effetti civili del matrimonio o ottenerne lo scioglimento secondo condizioni tra di esse concordate. Allo stesso modo si procede per la modifica delle condizioni di separazione o di divorzio. L'accordo non puo'contenere patti di trasferimento patrimoniale. L'atto contenente l'accordo e' compilato e sottoscritto immediatamente dopo il ricevimento delle dichiarazioni di cui al presente comma. L'accordo tiene luogo dei provvedimenti giudiziali che definiscono, nei casi di cui al comma 1, i procedimenti di separazione personale, di cessazione degli effetti civili del matrimonio, di scioglimento del matrimonio y di modifica delle condizioni di separazione o di divorzio" en https://www.gazzettaufficiale.it/eli/id/2014/09/12/14G00147/sg.

${ }^{56}$ Según el art. 54 de la Ley del Notariado de 28 de mayo de 1862 (Gaceta de Madrid núm. 149, de 29 de mayo de 1862), los cónyuges deberán prestar su consentimiento ante "el Notario del último domicilio común o el del domicilio o residencia habitual de cualquiera de los solicitantes". No obstante, pueden existir problemas de inadaptación en este ámbito (J. CARrascosa GonzÁlez, "Divorcio internacional...", loc.cit., p. 15). Las disposiciones de la Ley del Notariado no se adaptan a las particularidades que presentan los supuestos heterogéneos, por lo que, de lege ferenda, debería procederse a la reforma de dicha normativa, a efectos de evitar los problemas de adaptación que esta plantea en los supuestos internacionales. Al respecto vid. n. marchal escalona, "El tratamiento de la plurinacionalidad en el divorcio no judicial", Plurinacionalidad y Derecho Internacional Privado de Familia y Sucesiones, en M. MoYa Escudero (Dir.), Valencia, Tirant lo Blanch, 2021, pp. 449-453.

${ }^{57}$ Sobre la normativa aplicable y los foros de competencia internacional, vid., N. MARCHAL ESCALONA, "El tratamiento de la plurinacionalidad...", loc.cit. en op.cit., pp. 456-457.

${ }^{58}$ Es exigible, en todo caso, que los hijos mayores o menores emancipados otorguen su consentimiento ante el notario respecto de las medidas que les afecten por carecer de ingresos propios y convivir en el domicilio familiar (arts. 82 y 87 Código civil).
} 
monio, así como de los efectos derivados del divorcio (ex art. 90 Código civil $)^{59}$. Ahora bien, no hay que olvidar que España en este ámbito coexisten distintos ordenamientos jurídicos ${ }^{60}$. Algunos Derechos civiles autonómicos han desarrollado una regulación específica, en particular, sobre el carácter y contenido del convenio regulador ( $a d$ ex. Aragón ${ }^{61}$, Cataluña ${ }^{62}$, País Vasco ${ }^{63}$, Navarra ${ }^{64}$ ). La existencia de esta multiplicidad de regulaciones en España convierte en necesaria la articulación de estos diferentes Derechos. Esto es, resulta preciso determinar cuál es el derecho (común o autonómico) que resulta aplicable. En los conflictos de leyes internacionales resulta de aplicación uno u otro derecho, según lo dispuesto en el art. 36 del Reglamento (UE) $n^{\circ}$ 1259/2010 del Consejo, de 20 de diciembre de 2010, por el que se establece una cooperación reforzada en el ámbito de la ley aplicable al divorcio y a la separación judicial (en adelante Reglamento Roma III $\left.{ }^{65}\right) ;{ }^{66}$ mientras que en los conflictos de leyes internos el art. 16 de dicho Texto normativo, dispone que los Estados miembros "no tienen obligación alguna de aplicar el Reglamento a tales conflictos". No obliga, pero puede serlo, si así se decide. El legislador español ha optado por solucionar este problema desactivando la cláusula de exclusión de la normativa internacional vía indirecta al incorporar por referencia en el art. 107.2 ${ }^{\circ}$ Código civil las normas de la Unión Europea de Derecho internacional privado -en adelante DIPr.-. De esta manera, el legislador español, siguiendo a J. Pérez Milla, desactiva de forma implícita dicha cláusula de exclusión prevista en el Reglamento Roma III ${ }^{67}$. Dicha desactivación no es expresa, sino que es consecuencia directa del modelo de solución adoptado para resolver los conflictos de leyes internos (art. 16 Código civil) que remite a las soluciones del DIPr. (art. 107. $2^{\circ}$ Código civil). De esta manera, si para la solución de los conflictos internos en materia de disolución del matrimonio el art. 16 Código civil ordena la aplicación del art. $107.2^{\circ}$, y este remite, tras su modificación, al Reglamento Roma III, hay que entender que implícitamente se extiende el ámbito de aplicación del Reglamento a los conflictos internos.

El notario tiene la obligación de fiscalizar la legalidad del convenio regulador. De hecho, si alguno de los acuerdos del convenio pudiera ser dañoso o gravemente perjudicial para uno de los cónyuges o para los hijos mayores o menores emancipados afectados, deberá advertirlo a los otorgantes y se dará por terminado el expediente. Es decir, si el notario considera que el convenio es lesivo no podrá otorgar escritura pública de divorcio. En tal caso, deberá iniciarse el correspondiente proceso judicial. El control de lesividad establecido en este precepto atribuye al notario un cometido ajeno a la función notarial, puesto que va más allá del control de legalidad y le insta a ponderar la existencia de equidad. Se entiende

${ }^{59}$ En dicho convenio regulador se deben abordar, en su caso, aspectos tales como: la atribución del uso de la vivienda y ajuar familiar, la contribución a las cargas del matrimonio y alimentos, así como sus bases de actualización y garantías en su caso, la liquidación, cuando proceda, del régimen económico del matrimonio, y la pensión por desequilibrio que procede satisfacer, en su caso, a uno de los cónyuges (art. 90 Código civil).

${ }^{60}$ Sobre esta cuestión vid., A. Font I SEgURA, "La aplicación de instrumentos internacionales para regular el divorcio interregional” en Jornadas sobre Derecho, inmigración y empresa, (Coord. S. Ripol Carulla), Marcial Pons, Madrid, 2019, pp. 385-406.

${ }^{61}$ Art. 77 del Decreto Legislativo 1/2011, de 22 de marzo del Gobierno de Aragón, por el que se aprueba, con el título de «Código del Derecho Foral de Aragón», el Texto Refundido de las Leyes civiles aragonesas (BOA núm. 63, de 29 de marzo de 2011).

${ }^{62}$ Art. $233.2^{\circ}$ de la Ley 25/2010, de 29 de julio, del libro segundo del Código civil de Cataluña, relativo a la persona y la familia (DOGC núm. 5686, de 5 agosto 8 de 2010).

${ }^{63} \mathrm{El}$ art. 5 de la Ley $7 / 2015$, de 30 de junio, de relaciones familiares en supuestos de separación o ruptura de los progenitores (BOPV núm. 129, de 10 de julio de 2015).

${ }^{64}$ En Navarra, la crisis matrimonial o de pareja no está regulada expresamente en el Fuero Nuevo o Compilación del Derecho Civil Foral de Navarra (Ley 1/1973, de 1 de marzo, por la que se aprueba la Compilación del Derecho Civil Foral de Navarra -BOE núm. 57, de 7 de marzo de 1973-). No obstante, a partir del 16 de octubre de 2019, entró en vigor la nueva redacción y en parte nueva numeración de las Leyes dadas por la Ley Foral 21/2019, de 4 de abril, de modificación y actualización de la Compilación del Derecho Civil Foral de Navarra o Fuero Nuevo que regula los efectos respecto a los hijos de las situaciones de crisis matrimonial o de pareja (BON núm. 74 de 16 de abril de 2019). Igual sucede en Valencia con la Ley 5/2011, de 1 de abril, de relaciones familiares de los hijos e hijas cuyos progenitores no conviven (DOGV núm. 6495, de 5 de abril 4 de 2011).

${ }^{65}$ DOUE L 343 de 29 de diciembre de 2010, p. 10.

66 "Los Estados miembros participantes en los que se apliquen diferentes sistemas jurídicos o conjuntos de normas a las cuestiones reguladas por el presente Reglamento no estarán obligados a aplicarlo a los conflictos de leyes que se planteen exclusivamente entre esos sistemas jurídicos o conjuntos de normas".

${ }^{67} I d$., "El espacio del Derecho interregional tras los Reglamentos sobre obligaciones de alimentos y separación y divorcio", RDCA, XXIV, 2018-, pp. 43-45. 
que, para apreciar el carácter dañoso o gravemente perjudicial de un convenio, debe primar el principio de mínima intervención, para evitar generar un conflicto donde las partes han alcanzado un acuerdo, y debe atenderse a aspectos objetivos referidos a la estructura del acuerdo para concretar si existe (o no) lesividad ${ }^{68}$. Con todo, lo que, a nuestro juicio, resulta criticable es que, si alguno de tales acuerdos es lesivo, según lo expuesto, no pueda modificarse, como así se admite en otros ordenamientos jurídicos, y deba iniciarse el correspondiente proceso judicial.

Según el derecho español, los cónyuges deben intervenir en el otorgamiento de dicha escritura "de modo personal" (art. 82 Código civil). No se trata, a diferencia de lo que sucede en Derecho comparado, de un acto susceptible de delegación. Han de acudir los dos cónyuges, a la vez, a firmar la escritura. La prestación personal del consentimiento al divorcio ante el notario constituye, pues, un requisito imprescindible ${ }^{69}$ que, a nuestro juicio, resulta criticable. Sería deseable, como así sucede en otros sistemas jurídicos, la posibilidad de que estos pudieran delegar o nombrar un representante a tales efectos.

También resulta preceptiva la asistencia de los cónyuges en el otorgamiento de la escritura pública por Letrado en ejercicio (arts. 82 y 87 Código civil). Una exigencia que ha sido duramente criticada, puesto que dicha intervención obedece normalmente a la necesidad de contar con un asesoramiento especializado $^{70}$. No obstante, este decae en el ámbito notarial, por lo que, teniendo en cuenta la finalidad perseguida por la LJV (agilizar y abaratar los expedientes), lo lógico hubiese sido que no se hubiera impuesto dicha exigencia de forma preceptiva, sino que su intervención debería de haber contemplado de forma facultativa. No obstante, los intereses corporativos han determinado que, frente a la redacción inicial del Proyecto que no lo exigía, finalmente se imponga la asistencia letrada, por lo que habitualmente será el o los abogados de las partes a los que les corresponderá redactar el convenio, facilitárselo al notario y comparecer al otorgamiento de la escritura ${ }^{71}$.

27. En Francia se admite el "divorcio privado", aprobado por la Ley n ${ }^{\circ} 2016-1547$ de 18 de noviembre de 2016 de modernisation de la justice du XXIe siècle, que modificó el Código civil francés. A tenor de dicha Ley, el divorcio en Francia ha pasado a ser un asunto privado, basado en el acuerdo al que llegan los cónyuges ${ }^{72}$. No interviene autoridad pública alguna en su concesión. La autoridad notarial lo hace, pero el papel que este asume es mínimo ${ }^{73}$. Se trata, por tanto, de un divorcio "desjudicializado" y "contractualizado", cuya regulación legal no contempla norma alguna sobre la competencia territorial -ni interna ni internacional- convirtiéndolo en un "divorcio sin foro". Resulta factible obtenerlo, aunque no exista vinculación alguna con el territorio francés ${ }^{74}$. El Derecho francés admite este divorcio incluso en presencia de hijos menores, pero, aunque parezca contradictorio, concede a los hijos el «poder» de reconducir el divorcio de sus padres hacia un divorcio judicial ${ }^{75}$. La Circular dictada por el Ministerio

\footnotetext{
${ }^{68} \mathrm{http}$ //www.elnotario.es/409-hemeroteca/revistas/revista-67/6646-el-convenio-regulador-en-la-separacion-y-divorcionotariales-naturaleza-contenido-y-limites.

${ }^{69}$ Así, lo establece la Resolución-Consulta DGRN de 7 de junio de 2016, en la que dispone que: “[..]... Aunque no haya sido modificado el artículo 55 del Código Civil, y pudiera entenderse extensible su criterio a la escritura de divorcio, es meridianamente claro el artículo 82 inciso segundo del primer párrafo ... establece, en relación a la separación personal de los cónyuges, que estos deberán intervenir en el otorgamiento de modo personal, sin perjuicio de que deban estar asistidos por letrado en ejercicio, prestando su consentimiento ante el secretario judicial o el notario ... Por identidad de razón y a pesar de resultar agravado el criterio de exclusión de la representación en relación al matrimonio, incluso como nuntius, ha de considerarse necesaria la intervención personal y simultánea de los cónyuges, también en caso de divorcio, como requisito exigido por la ley del foro" en http://www.iurisprudente.com/2015/09/algunas-ideas-iniciales-sobre-el.html.

${ }^{70} \mathrm{http} / / /$ www.elnotario.es/index.php/opinion/opinion/5388-la-separacion-y-divorcio-notarial.

${ }^{71} \mathrm{http}: / /$ www.elnotario.es/index.php/opinion/opinion/5388-la-separacion-y-divorcio-notarial.

${ }^{72}$ C. Blanchard, "La fonction du notaire...", loc.cit., p. 1002.

${ }^{73}$ M. Pereña vicente, "El divorcio sin juez...", loc.cit., pp. 5-52.

${ }^{74}$ Un amplio sector de la doctrina francesa ha mostrado su perplejidad por esta reforma. Se ha llegado a cuestionar si el legislador ha querido convertir Francia en una especie de «Las Vegas del divorcio» (N. BALLON-WIRTZ, "La déjudiciarisation précipitée du divorce par consentement mutuel. Libres propos", La Semaine Juridique Edition Général, no 23, 2016, pp. 643 ss. 13; А. вогснÉ, “Divorce 229-1: aspect de droit international privé et europeen. La France, ¿nouveau Las Vegas du divorce?”, $A J$ Famille, 2017, p. 57; v. AVENA-ROBARDEt, "La Justice dans tous ses états”, AJ Famille, 2018, p. 3).

${ }^{75} \mathrm{El}$ art. 229-2 1..$^{\circ}$ ) del Código civil francés establece que: "cuando el menor, que ha sido informado por sus progenitores de su derecho a ser oído por el juez, solicite tal audición, se abre la vía judicial y no se permite continuar con la tramitación
} 
de Justicia de 26 de enero de $2017^{76}$ contempla las fases de la elaboración del acuerdo, el periodo de reflexión, la firma del acuerdo y su transmisión al notario ${ }^{77}$.

\section{C) Asia y África}

28. En Asia, tanto China como Kirguistán y Japón admiten el divorcio extrajudicial. En China, el art. 31 de la Marriage Law People's Republic of China contempla el divorcio ante el Encargado del Registro civil ${ }^{78}$, como así sucede también en Kirguistán (art. 18 del Family Code República Kirguisa ${ }^{79}$ ).

El Derecho civil japonés admite el divorcio de mutuo acuerdo (kyogi rikon) en los arts. 763 a 771. El divorcio consensual de carácter administrativo se basa en el principio de autonomía de la voluntad de los cónyuges ${ }^{80}$. Si ambas partes están de acuerdo con las condiciones de divorcio (reparto de bienes y patria potestad de los hijos), con solo llenar un formulario (rikon todoke) firmado por ambos cónyuges y otros dos testigos, el matrimonio queda disuelto ante el oficial del Registro Familiar, cuya oficina está en el Ayuntamiento de la localidad donde hayan contraído matrimonio ${ }^{81}$.

Mención especial merecen aquellos Estados en los que tribunales religiosos (Jordania ${ }^{82} \mathrm{e}$ Israel), Sharía Courts $\left(\right.$ Siria $^{83}$, Malasia ${ }^{84}$ Israel $^{85}$, península del Sinaí ${ }^{86}$, Líbano $^{87}$, Emiratos Árabes $^{88}$, Singapur ${ }^{89}$,

privada del divorcio". La doctrina ha criticado este «poder» que se concede al menor por las consecuencias nefastas que puede tener sobre el mismo desde un punto de vista afectivo o psicológico, descargando sobre él la responsabilidad de que el divorcio de sus padres sea judicial o convencional, asociándolo a una decisión que, en realidad, no le concierne, sacrificando la protección de su interés superior por otras consideraciones (M. Pereña Vicente, "El divorcio sin juez .... “, loc.cit., pp. 24-25).

${ }^{76}$ Circulaire du 26 janvier 2017 de présentation des dispositions en matière de divorce par consentement mutuel et de succession issues de la loi núm. 2016-1547 du 18 novembre 2016 de modernisation de la justice du XXIe siècle et du décret núm. 2016-1907 du 28 décembre 2016 relatif au divorce prévu à l'article 229-1 du code civil et à diverses dispositions en matière successorale (BOMJ núm. 2, 2017-06, du 30 juin 2017).

${ }^{77} \mathrm{El}$ acuerdo de divorcio corresponde hacerlo a los cónyuges, asistido cada uno por su abogado. No obstante, debe contener las menciones que el art. 229-3 del Código civil establece, entre ellas, la de que los hijos han sido informados de su derecho a ser oídos por el juez y que no desean hacer uso de esta facultad, debiendo aportarse para ello el formulario aprobado al efecto por la Arrêté de 28 de diciembre de 2016 (https://www.lexbase.fr/texte-de-loi/arrete-du-28-decembre-2016-fixant-lemodele-de-1-information-delivree-aux-enfants-mineurs-capables-d/L0120LCG.html). Además, debe mencionarse el nombre del notario que va a protocolizarla. Una vez redactado el acuerdo de divorcio, este debe ser comunicado por correo certificado con acuse de recepción a cada cónyuge por su abogado y, según el art. 229-4 del Código civil, se abre un periodo de reflexión de 15 días desde la recepción, durante el cual no se puede firmar, bajo sanción de nulidad. Transcurrido el plazo de reflexión el acuerdo puede ser firmado y, como confirma la Circular, los abogados deben asegurarse de la firma personal de cada cónyuge. Así, el acuerdo quedará establecido por «acto de abogado», firmado por las partes y refrendado por los abogados, con lo que atestan el consentimiento libre y consciente (éclairé) de su cliente. La firma de los cónyuges y de los abogados debe hacerse en un solo acto. Una vez firmado en tres ejemplares, se envía al notario que debe proceder a su protocolización en un plazo máximo de 7 días (M. Pereña Vicente, "El divorcio sin juez .... ", loc.cit., pp. 36-38).

78 "Divorce shall be granted if husband and wife both desire it. Both parties shall apply to the marriage registration office for divorce. The marriage registration office, after clearly establishing that divorce is desired by both parties and that appropriate arrangements have been made for the care of any children and the disposition of property, shall issue the divorce certificates" en https://www.cecc.gov/resources/legal-provisions/marriage-law-of-the-peoples-republic-of-china-amended. Para un análisis de la normativa China, vid. J.E. BORAO MATEO, "Legislación sobre matrimonio y familia en la República Popular China (RPC)- I", Encuentros en Catay, Universidad Fujen, n 27, pp. 46-87 en http://homepage.ntu.edu.tw/ borao/2Profesores/ Encuentros\%20en\%20Catay\%201.pdf.

${ }^{79}$ El matrimonio puede ser disuelto por el Encargado del Registro de actos del Estado Civil, salvo en los casos en los que hay menores de edad (art. 21), en cuyo caso, se disolverá por orden judicial en https://www.legislationline.org/documents/id/4950.

${ }^{80} \mathrm{https}$ //www.ideamatsu.com/matrimonio-divorcio/500-1-1.htm.

${ }^{81}$ E.M. ${ }^{a}$ Rodríguez DíAz, "El divorcio notarial...", loc.cit., pp. 76-77.

${ }^{82} \mathrm{https}: / /$ es.qaz.wiki/wiki/Law_of_Jordan.

${ }^{83} \mathrm{https}$ ://www.al-monitor.com/pulse/originals/2016/02/syria-extremist-factions-sharia-courts-aleppo-idlib.html.

${ }^{84} \mathrm{https}: / / \mathrm{www}$. state.gov/report/custom/19d47607c9/.

${ }^{85} \mathrm{https}: / / w w w . g o v . i 1 /$ en/departments/about/about_shariae.

${ }^{86} \mathrm{https} / / /$ foreignpolicy.com/2013/09/20/sharia-courts-of-the-sinai/.

${ }^{87} \mathrm{https}$ ://www.familysearch.org/wiki/en/index.php?title=Lebanon_Sharia_Court_Records\&mobileaction=toggle_view_ mobile.

${ }^{88} \mathrm{https}: / / \mathrm{www}$. international-divorce.com/uae divorce.htm.

${ }^{89} \mathrm{https} / /$ irblaw.com.sg/learning-centre/syariah-divorce-singapore-an-overview/. 
Pakistán $^{90}$, Nigeria ${ }^{91}$, Etiopia ${ }^{92}$ y Somalia $\left.{ }^{93}\right)$ o los Tribunales de Kadhi $\left(\right.$ Kenia $^{94}$, Tanzania ${ }^{95}$, Uganda y Gambia) tienen competencia para disolver un matrimonio, según la Sharía. Tales divorcios pueden plantear problemas de reconocimiento, como así se evidenció en los hechos que dieron lugar tanto al Auto del Tribunal de Justicia de la Unión Europea (en adelante TJCE) de 12 de mayo de 2016 (As. C-281/15: Sahyouni c. Mamisch ${ }^{96}$ ) como a la Sentencia dictada por el mismo Tribunal el 20 de diciembre de 2017 (As. C-372/16: Sahyouni $\mathrm{II}^{97}$ ). En tales decisiones el TJCE tuvo la oportunidad de pronunciarse sobre las cuestiones prejudiciales planteadas a raíz de la solicitud de reconocimiento en Alemania de una resolución de divorcio otorgada por un tribunal religioso sirio.

\section{Conclusiones}

29. El análisis que se ha llevado a cabo de Derecho comparado nos permite concluir que la diversidad es la nota dominante incluso en países que pertenecen a la misma área geográfica. No solo son diferentes las autoridades a las que los Estados confían competencias o facultades para disolver el matrimonio (notarios ${ }^{98}$, Encargados del Registro Civil ${ }^{19}$, alcaldes u otras autoridades públicas ${ }^{100}$ ), sino que también son diversas las funciones que estas autoridades pueden desempeñar. Así, por ejemplo, hay Estados en los que tales autoridades además de disolver el matrimonio pueden pronunciarse sobre otras cuestiones accesorias al matrimonio (liquidación del régimen matrimonial, guarda y custodia de los hijos, atribución de la vivienda familiar, etc.); mientras que otros condicionan o limitan la actuación de tales autoridades en este ámbito. Así, hay sistemas jurídicos que impiden acceder al divorcio extrajudicial si existen menores de edad (España, México, Brasil, Ecuador, Bolivia, Nicaragua y Rusia); mientras que otros lo admiten (Colombia, Cuba, Rumanía, Portugal, Italia, Dinamarca, Noruega). De igual manera, hay países que limitan el acceso a este tipo de divorcios si no se ha liquidado previamente el régimen

\footnotetext{
${ }^{90} \mathrm{https}: / /$ en.wikipedia.org/wiki/Federal_Shariat_Court.

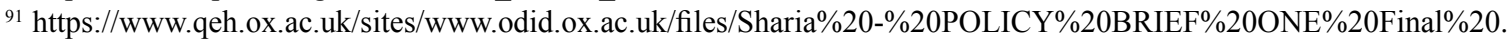

${ }_{92}$ M. AвDo, "Legal Pluralism, Sharia Courts, and Constitutional Issues", en https://68769-article\%20text-143258-1-1020110815.pdf.

${ }^{93}$ A. Iвrahim, “The Shari'a Courts of Mogadishu: Beyond “African Islam” and "Islamic Law”, en https://academicworks. cuny.edu/cgi/viewcontent.cgi?article $=3584 \&$ context $=$ gc_etds.

${ }^{94} \mathrm{https}$ //www.klrc.go.ke/index.php/constitution-of-kenya/136-chapter-ten-judiciary/part-3-subordinate-courts/339-170kadhis-courts.

${ }^{95} \mathrm{http} / / /$ www.commonlii.org/ke/other/KECKRC/2002/11.html.

${ }^{96}$ Rec. 2016, p. 1. Dicho Auto se pronunció sobre distintas cuestiones prejudiciales planteadas a raíz de la solicitud de reconocimiento en Alemania de una resolución de divorcio de un tribunal religioso sirio. En concreto, se le planteó si el Reglamento Roma III resultaba aplicable para reconocer dicho divorcio. El TJCE se declaró incompetente para pronunciarse sobre el tema. Para ello, argumentó que el asunto no planteaba un problema de ley aplicable, sino de reconocimiento de una resolución procedente de un tercer Estado, para lo que no existe una regulación europea aplicable. La doctrina criticó que dicho Tribunal no se esforzara en entender lo que el tribunal remitente había planteado (C.M. CAAMIÑa DomínguEz, "Divorcio privado dictado por un tribunal religioso de un tercer Estado: Asunto C-281/15: Soha Sahyouni y Raja Mamisch", $C D T$, vol. 9 , nº 2, 2017, pp. 629-634; M.A. García Sellens, C. Zimmer, "Reconocimiento y divorcios privados- Reflexiones a la luz del Auto del TJUE de 12 de mayo de 2016, asunto C-281/15, Sahyouni c. Mamisch", Bitácora Millenium DIPr., n 4, 2016, pp. 1-12). Dicho Tribunal dejó abierta la posibilidad de plantear una nueva cuestión prejudicial.

${ }^{97}$ Rec. 2017, p. 1. Dicha Sentencia es la respuesta que el TJCE dio a las cuestiones prejudiciales que fueron nuevamente planteadas por el Oberlandesgericht de Múnich ante el rechazo de dicho Tribunal a resolver si el Reglamento Roma III era aplicable (o no) al reconocimiento de un divorcio privado. Sobre la misma, vid. P. Diago Diago, "Inclusión de los divorcios privados en el ámbito de aplicación material del Reglamento 1259/2010 del Consejo, de 20 de diciembre de 2010: Sentencia del Tribunal de Justicia de la Unión Europea (Sala Primera) de 20 de diciembre de 2017, Asunto C-372/16: Sahyouni”, La Ley Unión Europea, $\mathrm{n}^{\circ}$ 58, 2018, pp. 1-11; M.A. GANDía Sellens/ C. Zimmer, "Los divorcios privados y el Reglamento Roma III Reflexiones a la luz de la Sentencia del TJUE de 20 de diciembre de 2017, asunto C-372/16, Sahyouni c. Mamisch”, Bitácora Millenium. DIPr., 2018, pp. 1-12.

${ }^{98}$ Así ocurre, por ejemplo, en derecho español, así como en la mayor parte de los sistemas iberoamericanos (L.B. PÉREZ Gallardo, "Un «fantasma» ...", loc.cit., pp. 1-43), en Letonia, Estonia y Rumania.

${ }^{99}$ Este sería el caso de China, México, Rusia, Rumania, Japón, Portugal, Italia, Letonia y Estonia.

${ }^{100}$ Así, por ejemplo, mientras que la Oficina del Gobernador del Condado se encarga de los trámites del divorcio en Noruega, en Dinamarca lo hace el Ministerio de Justicia (E.Ma . RodríguEz DíAz, "El divorcio notarial...," loc.cit., p. 77).
} 
económico del matrimonio (México) o tiene bienes compartidos (Letonia, Estonia, Bolivia, Nicaragua y Perú). En otros sistemas, limitan la actuación de las autoridades extrajudiciales en este ámbito al otorgarle competencia solo para disolver el matrimonio (Rusia, Ucrania y Armenia) teniendo las partes que acudir a la vía judicial para concretar las cuestiones accesorias al matrimonio (alimentos, menores, etc.).

30. Las diferencias en Derecho comparado se observan igualmente tanto en los prepuestos sustantivos (temporalidad ${ }^{101}$, existencia o no de hijos menores ${ }^{102}$, bienes en común o no del matrimonio, plazo de reflexión, ratificación) como procedimentales (asistencia de letrado ${ }^{103}$, presencia física o delegada de los cónyuges ${ }^{104}$, intervención del Ministerio Fiscal, autoridad competente) que han concurrir para que las autoridades no judiciales puedan autorizar dicho divorcio. Con todo, la mayor parte de los sistemas jurídicos que aceptan este tipo de divorcios exigen unánimemente, salvo excepciones ( $a d$ ex. Rusia), mutuo acuerdo de los cónyuges, así como la existencia de un convenio o acuerdo regulador de sus relaciones (autonomía de la voluntad material) en el que se plasme la voluntad de los mismos.

\section{Condicionantes de la eficacia del divorcio extrajudicial extranjero en España}

31. La diversidad existente en Derecho comparado en este ámbito, junto a los diferentes pronunciamientos que puede se pueden obtener tras la disolución extrajudicial del matrimonio (disolución del régimen económico del matrimonio, obligaciones de alimentos, guarda y custodia y derechos de visita), así como la pluralidad de fuentes normativas existente en el sistema jurídico español (institucional, convencional y estatal) complica, sobremanera, saber cómo se reconoce en España un divorcio extrajudicial obtenido en el extranjero. Y, en particular, porque el concepto de "resolución judicial" que tales normas contemplan a efectos de su aplicación divergen de una norma a otra, lo que resulta fundamental para saber si las decisiones extranjeras en las que constan tales divorcios deben de ser reconocidas en España como "resoluciones judiciales" o como "documentos públicos".

No obstante, podemos anticipar que el régimen jurídico aplicable al reconocimiento de un divorcio extrajudicial extranjero dependerá principalmente del tipo de divorcio que se haya obtenido. Esto es, si este ha sido otorgado por una autoridad extrajudicial extranjera (notarial, registral o administrativa) que ha intervenido desempeñando una función constitutiva, o se trata de un mero "divorcio privado" en el que no ha intervenido autoridad o su función ha sido meramente recepticia de la voluntad de los cónyuges. Como tendremos ocasión de analizar, existen mayores problemas para reconocer en España los "divorcios privados" obtenidos en el extranjero, en particular, los que proceden de autoridades religiosas, aunque posteriormente sean visados por autoridad pública.

32. Por su parte, saber cuál es el régimen jurídico aplicable al reconocimiento de un divorcio otorgado por autoridad extrajudicial extranjera en una cuestión tan esencial como compleja, que depende, entre otros factores, del efecto (constitutivo, ejecutivo o probatorio) que se pretenda obtener con su reconocimiento. Asimismo, debe tenerse en cuenta que las autoridades que otorgan este tipo de divorcios pueden tener competencia tanto para disolver el matrimonio como para pronunciarse sobre otras cuestiones accesorias al mismo (alimentos, menores, etc.), lo que complica saber cómo han de reconocerse en nuestro país. Por una parte, porque las partes pueden pretender el reconocimiento global

\footnotetext{
${ }^{101}$ Hay ordenamientos jurídicos en los que debe de haber transcurrido un período mínimo de 3 meses, desde que se celebró el matrimonio, para que se pueda autorizarse un divorcio no judicial ( $\mathrm{d}$ ex. derecho español), frente a otros que exigen dos años (ad ex. derecho brasileño). Aunque hay sistemas jurídicos que no establecen la necesidad de que exista plazo de tiempo alguno (ad ex. derecho cubano, colombiano, peruano, nicaragüense y ecuatoriano).

${ }^{102}$ Así pues, mientras que algunos Estados solo admiten el divorcio extrajudicial cuando no hay hijos menores (ad ex. España, Perú, Nicaragua, Bolivia, México, y Ecuador), a otros les resulta indiferente (ad ex. Cuba, Colombia).

${ }^{103}$ Así, por ejemplo, hay sistemas jurídicos, como el español, brasileño, ecuatoriano y colombiano, donde la asistencia de letrado es preceptiva; mientras que en otros no lo es ( $a d$ ex. derecho cubano, peruano y nicaragüense).

${ }^{104}$ Hay sistemas jurídicos, como así sucede en España, que exigen la presencia física de los cónyuges ante la autoridad competente para proceder a disolver el matrimonio, mientras que en otros no se requiere o permite la delegación.
} 
de todos los pronunciamientos de la decisión extranjera (de la disolución del vínculo y de las cuestiones accesorias al mismo), o también cabe la posibilidad de un reconocimiento parcial, es decir, solo de algunos de los pronunciamientos contenidos en ella, siempre que ello resulte factible. Y, por otra, por la pluralidad de fuentes normativas (institucional, convencional y estatales) que en Derecho español existe en estas materias (alimentos, menores, etc.) y, sobre todo, por la diversidad con la que tales normas definen conceptos claves para su aplicación, como así sucede con el término "resolución judicial". Tal concepto diverge según la norma aplicable, aunque hay una tendencia generalizada, sobre todo, en la normativa institucional, a relacionar y unificar, como veremos, dicho concepto con la noción de "órgano jurisdiccional". La identificación de si dicha autoridad actúa (o no) como "órgano jurisdiccional" es relevante para saber si el acto por el que se disuelve el matrimonio debe ser reconocido en España como una "resolución judicial" o como un "documento público". A ello hay que unir, que las cuestiones accesorias al mismo y, en particular, las relativas a la liquidación del régimen económico del matrimonio pueden constar formalmente en documentos diferentes, como así sucede en aquellos Estados que exigen que dicha liquidación tenga lugar de forma previa para acceder a este tipo de divorcios.

33. Con todo, lo que determina el régimen jurídico aplicable al reconocimiento, de tales divorcios y, en concreto, si son reconocidos como "resoluciones judiciales" o "documentos públicos" extranjeros, es la función que desempeña la autoridad que lo autoriza cuando lo pronuncia. Y, en concreto, si esta es (o no) equivalente a la que realizan las autoridades judiciales españolas cuando disuelven el vínculo matrimonial. La identificación de la normativa aplicable no depende, pues, de la autoridad que interviene en el divorcio, sino de la "función jurisdiccional" que pueden ejercer tales autoridades externas a la estructura judicial, pero que, sin embargo, ejercen funciones jurisdiccionales por atribución legal. Tal exigencia requiere determinar hasta qué punto tales decisiones son equivalentes a las resoluciones judiciales sobre la materia.

A continuación, procederemos a analizar el régimen de reconocimiento de tales divorcios en nuestro país, así como de las cuestiones accesorias que pueden derivarse del mismo.

\section{Efecto constitutivo del divorcio otorgado en el extranjero}

\section{Régimen de reconocimiento en España del divorcio otorgado por autoridad extrajudicial ex- tranjera}

34. Saber cómo se reconoce en España una decisión de divorcio otorgada por autoridad extrajudicial extranjera, así como los aspectos que deben de controlarse de la misma y la vía de atribución de eficacia (execuátur vs. reconocimiento automático) depende de dos factores, a saber: por una parte, de la norma aplicable a su reconocimiento y, por otra, del efecto pretendido. No siempre es necesario la tramitación de un procedimiento de execuátur para que un divorcio pronunciado u otorgado por autoridad no judicial extranjera despliegue efectos en nuestro país. Es posible que el mismo sea utilizado en España con valor simplemente probatorio, en cuyo caso será tratado como un simple documento público, exigiéndosele sin más el cumplimiento de los requisitos a los que los arts. 144 y $323.2^{\circ}$ de la Ley 1/2000, de 7 de enero, de Enjuiciamiento Civil (en adelante LEC $^{105}$ ) condiciona la eficacia probatoria en juicio de los documentos públicos extranjeros (en concreto, traducción -que, de conformidad con el art. 144 LEC "podrá ser hecha privadamente"-y legalización, siempre que ello sea preciso).

35. En el Derecho español vigente, la pluralidad de fuentes institucionales, convencionales y estatales existentes convierte a la identificación del régimen de reconocimiento de la decisión de divorcio extrajudicial extranjero en una cuestión tan esencial como compleja.

${ }^{105}$ BOE de 8 de enero de 2000. 
En el espacio judicial europeo cabe destacar al Reglamento (CE) $n^{0}$ 2201/2003 del Consejo de 27 de noviembre de 2003 relativo a la competencia, el reconocimiento y la ejecución de resoluciones judiciales en materia matrimonial y de responsabilidad parental, por el que se deroga el Reglamento (CE) $\mathrm{n}^{\mathrm{o}} 1347 / 2000$ (en adelante RBr II bis) ${ }^{106}$. Esta norma constituye la pieza clave del reconocimiento de aquellas decisiones de divorcio procedentes de Estados miembros. Cuestión distinta es saber si resulta aplicable (o no) al reconocimiento de este tipo de divorcios. Por su parte, en el ámbito bilateral hallamos también una serie de convenios que serán aplicables, siempre que su ámbito de aplicación (material, espacial y temporal) lo permita, y no hayan sido desplazados por el RBr II bis (art. 59). Y, por último, cabe mencionar el régimen autónomo o estatal, cuya aplicación es residual, y en el que cabe cifrar, a su vez, un nutrido cuerpo normativo, a saber: la Ley 15/2015 de Cooperación jurídico internacional en materia civil (en adelante LCJIMC ${ }^{107}$ ), la Disposición Adicional Segunda y los arts. 11 y 12 de la LJV, respectivamente.

Concretar cuál es la norma aplicable al reconocimiento de un divorcio extrajudicial dependerá de una serie de factores: del país del que proceda dicho divorcio, de la fecha en la que se otorgó el mismo, así como del efecto que se pretenda obtener con su reconocimiento (constitutivo, probatorio o registral). Pero, fundamentalmente, y como hemos avanzado, lo que determinará el régimen jurídico aplicable al reconocimiento de tales divorcios en España es si la autoridad extranjera que lo ha otorgado ha ejercido (o no) "función jurisdiccional" alguna. Esto es, si esta es (o no) equivalente a la que desempeñan las autoridades judiciales españolas cuando disuelven un matrimonio.

\section{A) Derecho institucional}

36. Si el divorcio extrajudicial obtenido en el extranjero procede de un Estado miembro del $\mathrm{RBr}$ II bis, esto es, de Portugal, Italia, Lituania, Letonia y Rumania, será de aplicación este instrumento normativo para el reconocimiento de tales divorcios en España, al incorporar dicho Reglamento un concepto amplio de "resolución judicial". Considera como tal tanto las dictadas por autoridades judiciales como por las no judiciales, siempre que sean en las materias reguladas en dicho Reglamento (art. $\left.2.1^{\circ}\right)^{108}$. A tenor de dicha definición, las autoridades españolas deberán aplicar el RB II bis al reconocimiento de tales divorcios en España, pero, por razones obvias, estas deberán de hacerlo con las adaptaciones oportunas al tratarse de un instrumento normativo dedicado principalmente al reconocimiento de las resoluciones judiciales de divorcio.

Así pues, tales divorcios podrán surtir efectos en España a través del reconocimiento automático o execuátur. Tanto uno como otro presentan un elemento común: el control que en ambos casos la autoridad competente lleva a cabo las condiciones a las que dicho Reglamento supedita el reconocimiento del divorcio extranjero. En particular, los motivos por los que se podría denegar el reconocimiento de este tipo de divorcios en nuestro país están limitados y son muy concretos y tasados. Solo podría denegarse el reconocimiento de un divorcio extrajudicial extranjero, si ello fuera manifiestamente contrarios al orden público español [art. 22 a) RBr II bis], o si la decisión de divorcio fuere inconciliable con una resolución anterior dictada en España u otro Estado [art. 22 c) y d) RBr II bis]. Ni la regularidad del proceso seguido en el extranjero ni el hecho de que la autoridad extrajudicial extranjera careciera de competencia internacional [art. $24 \mathrm{RBr}$ II bis)] constituirían obstáculo alguno para su reconocimiento. Sería indiferente, pues, tanto la norma de competencia internacional en base a la cual la autoridad no judicial hubiera determinado su competencia como ley aplicada por aquella (arts. $26 \mathrm{y}$ 22 a sensu contrario $\mathrm{RBr}$ II bis), lo que eleva exponencialmente las posibilidades para que este tipo de divorcios surtan efectos en nuestro país.

${ }^{106}$ DOUE L 338 de 23 de diciembre de 2003, p. 1. Dicho Reglamento será derogado, a partir del 1 de agosto de 2022 (art. 104), por el Reglamento (UE) $n^{\circ}$ 2019/1111 del Consejo, de 25 de junio de 2019, relativo a la competencia, el reconocimiento y la ejecución de resoluciones en materia matrimonial y de responsabilidad parental, y sobre la sustracción internacional de menores (DOUE L 178 de 2 de julio de 2019, p. 1).

${ }^{107}$ BOE de 31 de julio de 2015.

${ }^{108}$ P. JIMÉNEZ BLANCO, “Concepto de "órgano jurisdiccional” en los Reglamentos de DIPR”, AEDIPr., t. XIX-XX, 20192020, pp. 121-162, en esp. pp. 151-152. 


\section{B) Derecho convencional}

37. En defecto de norma institucional aplicable, el divorcio otorgado por autoridad extrajudicial extranjera podrá surtir efectos en nuestro país de conformidad a lo establecido en los Tratados y convenios internacionales bilaterales suscritos por España. Tales instrumentos, no obstante, serán de aplicación siempre que así lo permita su ámbito de aplicación material e incorpore un concepto amplio de "resolución judicial". Este debe comprender no solo a las decisiones dictadas por autoridades judiciales, sino también a las no judiciales ${ }^{109}$.

A la luz de lo cual, cabe concluir la escasa o nula operatividad práctica de los convenios bilaterales que España tiene suscritos con aquellos países que admiten este tipo de divorcio. En unos casos, porque aquellos han sido desplazados en su aplicación por el RBr II bis, como así sucede con el convenio hispanoitaliano ${ }^{110}$, en otros, porque el divorcio constituye una materia expresamente excluida de su ámbito de aplicación, como así sucede con el convenio hispano-brasileño ${ }^{111}$, el convenio hispano-rumano ${ }^{112}$ o el hispanomexicano ${ }^{113}$. Mientras que en otros supuestos, su exclusión se debe a que tales normas solo contemplan el reconocimiento de "resoluciones judiciales" extranjeras, como así ocurre con el convenio hispano-colombiano (art. 1) $)^{114}$, el convenio hispano-chino ${ }^{115}$, cuyo ámbito de aplicación se circunscribe únicamente al de las sentencias o fallos de tribunales de justicia (art. $2.3^{\circ}$ ), o el Convenio hispano ruso ${ }^{116}$, como así ha reconocido la Dirección General de los Registros y del Notariado (en adelante DGRN) en la Resolución dictada el 14 de mayo de 2001, sobre inscripción de divorcio ante el Encargado del Registro Civil promovido en Rusia ${ }^{117}$.

\section{C) Derecho autónomo}

38. En defecto de normativa internacional aplicable, el régimen jurídico aplicable al reconocimiento de una decisión de divorcio otorgada por autoridad extrajudicial extranjera dependerá de la normativa estatal. El problema reside en que en este ámbito la normativa estatal se caracteriza por una pluralidad normativa. Puede ser de aplicación tanto lo dispuesto en la Disposición adicional tercera o en los arts. 11 o 12 de la LJV, en la LCJIMC (art. $41.2^{\circ}$ ) como en los arts. 323 y 144 de la LEC. Saber cuándo resulta aplicable una u otra norma y, por tanto, qué condiciones deberán controlar las autoridades españolas para otorgar eficacia a una decisión de divorcio pronunciada por autoridad extrajudicial extranjera, es una cuestión compleja que depende no solo del tipo de divorcio que se haya obtenido en el extranjero (notarial, registral, etc.) y, por ende, del tipo documento cuyo reconocimiento se pre-

\footnotetext{
${ }^{109}$ J. CARRAScosa GonZÁlez, "Divorcio internacional...”, loc.cit., p. 22.

${ }^{110}$ Convenio entre España e Italia sobre asistencia judicial y reconocimiento y ejecución de sentencias en materia civil y mercantil, firmado en Madrid el 22 de mayo de 1973 (BOE de 15 de noviembre de 1977).

${ }^{111}$ Convenio de cooperación jurídica en materia civil, entre el reino de España y el Gobierno de la República Federativa de Brasil, hecho en Madrid el 13 de abril de 1989 (BOE de 10 de julio de 1991.Correc.err., BOE 193, de 13 de agosto de 1991).

${ }^{112}$ Convenio entre España y Rumania sobre competencia judicial, reconocimiento y ejecución de decisiones en materia civil y mercantil, hecho «ad referendum» en Bucarest el 17 de noviembre de 1997 (BOE de 5 de junio de 1999).

${ }^{113}$ Convenio sobre reconocimiento y ejecución de sentencias judiciales y laudos arbitrales en materia civil y mercantil entre los Estados Unidos Mexicanos y el Reino de España, hecho en Madrid, el 17 de abril de 1989 (BOE de 9 de abril de 1991. Coorrec.err. BOE de 6 de mayo y 226, de 20 de septiembre de 1991).

${ }^{114}$ Convenio entre España y Colombia sobre ejecución de sentencias civiles de 30 de mayo de 1908 (Gaceta de Madrid de 18 de abril de 1909).

${ }^{115}$ El Tratado entre el Reino de España y la República Popular China sobre asistencia judicial en materia civil y mercantil, hecho en Pekín el 2 mayo 1992 (BOE de 31 de enero de 1994.Correc.err. BOE de 11 de marzo de 1994).

${ }^{116}$ Convenio entre España y la Unión de Repúblicas Socialistas Soviéticas sobre asistencia judicial en materia civil, firmado en Madrid el 26 octubre 1990 (BOE de 25 de junio de 1997).

${ }^{117}$ La DGRN consideró que: “... [ ] no puede ser aplicable el convenio sobre asistencia judicial citado en los vistos ya que claramente (cfr. art. 17 del convenio) el mismo sólo se refiere al reconocimiento y ejecución de resoluciones judiciales, por lo que el supuesto contemplado (divorcio por mutuo acuerdo y sin intervención judicial) no puede estar incluido en modo alguno. Por todo ello se hace necesario que dicho acuerdo de divorcio sea declarado conforme con la legislación española por medio del procedimiento legal oportuno y ello porque si es necesario el exequatur tratándose de sentencias y resoluciones judiciales, con mayor razón es necesario este requisito, cuando no ha intervenido tribunal alguno en el proceso de disolución del vínculo matrimonial".
} 
tenda obtener (escritura notarial, resolución extrajudicial o acto público), sino también del efecto que se pretenda con su reconocimiento (sea registral, constitutivo o probatorio). Pero, fundamentalmente, dependerá, como ya hemos adelantado, de la función que dicha autoridad hubiera desempeñado en su otorgamiento, es decir, si esta es equivalente o no a la que ejercen las autoridades judiciales españolas cuando intervienen en este ámbito. De dicha cuestión dependerá que el divorcio extrajudicial extranjero sea reconocido como "resolución judicial" o como "documento público" extranjero.

39. Así pues, en defecto de normativa institucional e internacional, y cuando la autoridad extrajudicial extranjera desempeñe funciones equivalentes a las que, según el Derecho español, corresponden a las autoridades judiciales españolas, resultará de aplicación lo establecido en la LJV (ex art. 11.3 ${ }^{\circ}$ $\mathrm{LJV}^{118}$ ) y, en particular, en los arts. 11 y $12.3^{\circ} \mathrm{LJV}$ que prevalecen sobre la LCJIMC [ex Disposición adicional primera g) LCJIMC] ${ }^{119}$. Estas disposiciones regulan, aunque de forma confusa, los efectos legales que pueden desplegar en España los actos de jurisdicción voluntaria cuando la autoridad extrajudicial extranjera desempeñe funciones equivalentes a las que, según el Derecho español, corresponden a las autoridades judiciales españolas. Tales normas serán de aplicación cuando se pretenda la eficacia registral de este tipo de divorcios en España (arts. 11 y $12.3^{\circ} \mathrm{LJV}^{120}$ ); mientras que lo dispuesto en la LCJIMC lo será cuando se pretenda la eficacia constitutiva del mismo (art. $41.2^{\circ}$ ).

Tales normas resultan aplicables para reconocer en España aquellos divorcios otorgados por autoridades extrajudiciales procedentes de Iberoamérica (Colombia, Cuba), países nórdicos (Dinamarca, Noruega), europeos (Moldavia) y asiáticos (China y Japón) en los que tales autoridades están facultadas para desempeñar las mismas funciones que realizan las autoridades judiciales españolas cuando disuelven un matrimonio. Para que una decisión de divorcio procedente de tales países pueda ser reconocida y ser inscrita en el Registro civil español, es preciso que reúna los requisitos que establece el art. 12.3 ${ }^{\circ}$ LJV -a la que remite el art. 11 LJV- . En primer lugar, esta debe haber sido dictado por autoridad extranjera con competencia para ello [art. $12.3^{\circ}$ a) LJV]. Se considera que dicha autoridad será competente si el supuesto presenta vínculos fundados con el Estado extranjero cuyas autoridades han otorgado dicho acto. Ello sucederá, según la presunción juris et de jure que dicho precepto establece, cuando el supuesto afecte a una materia cuya competencia exclusiva corresponda a los órganos judiciales o autoridades españolas. No obstante, dicho control debe extenderse igualmente a aquellas decisiones que, sin llegar a conculcar competencias exclusivas de nuestros Tribunales, obedecen a un foro de competencia manifiestamente exorbitante. Para determinar dicho carácter, se deberán bilateralizar las normas de competencia directa previstas en el RBr II bis.

En segundo lugar, el reconocimiento de tales divorcios en nuestro país podría ser denegado si hubiera sido acordado con manifiesta infracción de los derechos de defensa de cualquiera de los implicados. Es evidente que este motivo no será obstáculo para que tales divorcios surtan efectos en España, toda vez que en ellos existe mutuo acuerdo de las partes en divorciarse. No obstante, sí podría denegarse su reconocimiento si ello fuera manifiestamente contrario al orden público español o implicara la violación de un derecho fundamental o libertad pública de nuestro ordenamiento jurídico.

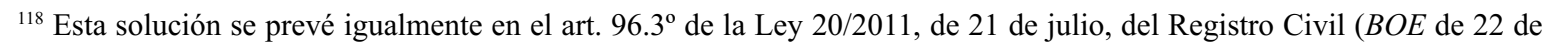
julio de 2011), norma que resultará de aplicación preferente cuando entre en vigor. Sobre dicho precepto, N. MARCHAL ESCALONA, "El futuro régimen autónomo de reconocimiento de decisiones judiciales extranjeras con acceso al Registro Civil Español”, $L a$ Ley Unión Europea, no 4, 2013, pp. 28-43.

${ }^{119}$ De hecho, el Tribunal Supremo ha homologado dediciones sobre divorcio dictados por notarios extranjeros y por autoridades administrativas con competencia para decidir sobre determinadas cuestiones matrimoniales. Al respecto y citando abundante jurisprudencia, vid. R. ARENAS GARCíA, Crisis matrimoniales internacionales. Nulidad matrimonial, separación $y$ divorcio en el nuevo derecho internacional privado español, Universidade de Santiago de Compostela, Servicio de Publicaciones e Intercambio Cientifico, 2004, pp. 352-353.

${ }^{120}$ La regulación contenida en tales preceptos ha sido objeto de crítica. No queda clara la delimitación existente entre el régimen previsto para los «expedientes y actos de jurisdicción voluntaria», que contempla expresa, pero no únicamente, su acceso a los registros públicos (art. $12 \mathrm{LJV})$, y el previsto en el art. 11 para las «resoluciones» judiciales. Al respecto, vid. J.C. FernándeZ RoZAS/ S. SÁnCHeZ loRenzo, Derecho internacional..., op.cit., p. 410. 
Por el contrario, si lo que se pretende es la eficacia constitutiva de la decisión extranjera en la que conste el divorcio deberá tramitarse el oportuno execuátur (art. 42 LCJIMC) ${ }^{121}$.

40. Ahora bien, si el divorcio es otorgado por una autoridad extrajudicial extranjera, y esta no hubiera desempeñado una función equivalente a la que desempeñan las autoridades judiciales españolas, como así sucede con aquellos procedentes de ciertos países de Iberoamérica (México, Brasil, Ecuador, Nicaragua, Bolivia y Perú), de Europa (Rusia, Moldavia y Ucrania), Asia (Kirguistán) o transcontinentales (Armenia), tales decisiones no podrían ser reconocidas como "resoluciones judiciales", sino como "documentos públicos" extranjero. El régimen legal de reconocimiento aplicable, así como las condiciones a controlar por las autoridades españolas, dependerán del efecto pretendido. Así pues, si lo que se pretende es su eficacia registral, será de aplicación lo dispuesto en la Disposición adicional tercera de la LJV. Esta norma exige, entre otras condiciones, el control de la competencia de la autoridad que lo hubiera dictado. Atendiendo a esta condición, solo serían reconocidas aquellas decisiones de divorcio otorgadas por autoridades extrajudiciales competentes excluyendo su reconocimiento en caso de competencias exorbitantes. La regla es, en principio, razonable y supone, como ya se ha expuesto, la necesidad de bilateralizar la normativa de competencia a efectos de controlar la de la autoridad de origen. Además, para su reconocimiento, dicha autoridad debe de haber desempeñado funciones equivalentes a las que ejercen las autoridades españolas en la materia de que se trate y surta los mismos o más próximos efectos en el país de origen. El control que este precepto impone en relación con los efectos que ha de cumplir la decisión de divorcio extranjero no responde a parámetros de "identidad absoluta", sino de "equivalencia", por lo que, para que dicho reconocimiento se produzca, será suficiente que aquella tenga sustancialmente los mismos efectos, aunque no sean idénticos. Por último, se exige también que el hecho o acto contenido en el documento sea válido conforme al ordenamiento designado por las normas españolas de Derecho internacional privado y que la inscripción del documento extranjero no resulte manifiestamente incompatible con el orden público español.

Por el contrario, si el efecto pretendido fuera el constitutivo o el probatorio sería aplicable lo dispuesto en los arts. 323 y 144 LEC que imponen el respeto de las condiciones de validez exigidas por la ley aplicable conforme a nuestro sistema de Derecho internacional privado. No sería posible llevar a cabo un control de la competencia de la autoridad de origen, ni tampoco sería preciso tramitar el correspondiente execuátur del mismo, como así se estimó en el Auto de la Audiencia Provincial de Alicante (Secc. $4^{\mathrm{a}}$ ), de 27 de noviembre de 2019, en el que se denegó la tramitación de dicho procedimiento para reconocer en España un acta notarial otorgada en San Francisco de Quito (Ecuador) en la que se disolvía un matrimonio. ${ }^{122}$.

\section{El régimen de reconocimiento de los “divorcios privados" extranjeros en España}

41. En este epígrafe analizaremos la eficacia en España de aquellos divorcios que son fruto del mero acuerdo de las partes, como así sucede en Derecho francés o en aquellos otros países que son dictados por tribunales religiosos, y que son visados posteriormente por una autoridad pública que interviene desempeñando una función meramente recepticia. De hecho, estos últimos se caracterizan precisamente porque sus decisiones carecen de efecto constitutivo alguno. Y este es, fundamentalmente, el principal obstáculo que existe para ser reconocidos, puesto que el documento en el que se declara el divorcio no

${ }^{121}$ Así ocurrió, por ejemplo, en el Auto de la Audiencia Provincial de Cádiz, Sección Quinta, de 24 de mayo de 2018, al estimar el recurso de apelación interpuesto contra el Auto dictado por el Juzgado que otorgó el execuátur aplicando la LCJIMC a una resolución de disolución del matrimonio dictada por el Gobernador del Condado de Nordland (Noruega). El Auto dictado por la Audiencia Provincial de San Sebastián, Sección Segunda, de 14 de septiembre de 2018, por la que confirmaba el execuátur de una sentencia de divorcio dictada por el Juzgado de Familia de Tokio aplicó también dicha norma (ECLI: ES:APSS:2018:1222A), al igual que en el Auto de la Audiencia Provincial de Vitoria-Gasteiz (Secc. $1^{\text {a }}$ ), de 8 de julio de 2019, que estimó el recurso contra el Auto dictado por el Juzgado de Primera Instancia en un procedimiento de execuátur, revocando el mismo y, en consecuencia, decretando la admisión a trámite de una demanda execuátur para el reconocimiento del documento público de escritura de cese de efectos civiles suscrito por un notario de Colombia (ECLI: ES:APVI:2019:401ª).

${ }^{122}$ ECLI: ES:APA:2019:663a 
merece el calificativo de "decisión extranjera" al no haber sido dictada por una autoridad revestida de imperium con capacidad de control sobre los requisitos precisos para que puede ser decretado el divorcio $^{123}$. Ahora bien, el hecho de que este tipo de divorcios no puedan surtir efectos jurídicos en España como una decisión extranjera, no significa, a priori, que no puedan ser reconocidos ${ }^{124}$.

Como veremos, esta es una cuestión que depende del tipo del divorcio que se haya obtenido en el extranjero.

\section{A) ¿Pueden ser los divorcios pronunciados por tribunales religiosos extranjeros reconocidos en España?}

42. Para que un divorcio dictado por un tribunal religioso extranjero sea reconocido en España, debería procederse a un reconocimiento conflictual del mismo ${ }^{125}$. Esto es, conforme a la ley aplicable al divorcio $^{126}$. El divorcio religioso extranjero se consideraría válido si reuniera los requisitos sustantivos y formales establecidos por el Derecho al que remita la norma de conflicto española pertinente ${ }^{127}$. La cuestión que se plantea de inmediato es saber la norma conforme a la que deberá realizarse dicho control. Según la Sent. del TJCE dictada en el asunto Sahyouni, el Reglamento Roma III no se aplica al reconocimiento de una resolución de divorcio religioso dictada en un tercer tercero sin la intervención de una autoridad pública, ya sea consecuencia de la voluntad unilateral o común de las partes ${ }^{128}$. En defecto, pues, de norma institucional y convencional aplicable, el reconocimiento de tales divorcios debería llevarse a cabo, según lo previsto en la ley aplicable ex art. 107.2 ${ }^{\circ}$ Código civil español.

La cuestión está en que dicho precepto no regula propiamente cuál es la ley aplicable divorcio, por lo que su aplicación práctica sitúa al operador práctico en un callejón sin salida. Y ello porque este artículo remite, en primer lugar, a lo dispuesto en la normativa de la Unión Europea y, por ende, al Reglamento Roma III, norma que, como ha apuntado el TJCE, no resulta aplicable a estos supuestos. Y, en segundo lugar, porque se refiere igualmente a lo establecido "en la normativa española de Derecho internacional privado". Una remisión que cabe calificar, según la doctrina española, de enigmática e incomprensible ${ }^{129}$. No se entiende bien a qué se refiriere el legislador español cuando dicho precepto alude a las normas españolas de Derecho internacional privado, puesto que tales disposiciones, desde que se reformó el tenor literal del art. 107.2 ${ }^{\circ}$ Código civil, dejaron de existir. A la luz de lo cual, cabe concluir, que en el ordenamiento jurídico español no existe una regulación ni internacional ni estatal específica conforme a la cual pueda llevarse a cabo dicho reconocimiento conflictual. Su ausencia evidencia la existencia de una laguna normativa en DIPr. español para proceder al reconocimiento conflictual, así como la incapacidad de reconocer en España de aquellos divorcios dictados por tribunales religiosos extranjeros. Ello no impide, no obstante, que la parte interesada solicite directamente el divorcio a nuestros tribunales. A nuestro juicio, esta situación hubiera podido evitarse, si el legislador español hubiera incorporado materialmente -en lugar de hacerlo por referencia- lo dispuesto en la reglamentación europea.

De lege ferenda, debería reformarse el sistema estatal español para evitar estas lagunas. Con todo, de existir un corpus normativo a partir del cual realizar dicho control, sería preciso saber si tales divorcios podrían ser reconocidas (o no) en nuestro país (o no) por ser contrarias al orden público español, tal y como ha apuntado recientemente la sentencia dictada por el Bundesgerichtshof alemán (en adelante $\mathrm{BGH}^{130}$ ) de 26 de agosto de 2020 -tribunal que planteó al TJCE las cuestiones prejudiciales que

${ }^{123}$ Sobre esta cuestión, vid. A.L. Calvo caravaca, J. Carrascosa GonZÁlez, Derecho internacional..., op.cit., p. 305.

${ }^{124}$ En sentido contrario, M.A. GARCÍA SELLENS, C. ZIMMER, “Reconocimiento y divorcios privados...”, loc.cit., p. 7.

${ }^{125}$ A. Álvarez GonzÁlez, "Sahyouni. Más allá del espejo...”, loc.cit., p. 19 y bibliografía ibid. citada.

${ }^{126}$ R. Arenas García, Crisis matrimoniales..., op.cit., p. 351 en esp. nota pp. núm. 351; F.J. Garcimartín Álferez, Derecho internacional privado. Cizur Menor (Navarra), Thomson Reuters/Civitas, 2019, 5a ed., p. 279.

${ }^{127}$ S.L. Göss, "Open Issues in European International Family Law: Sahyouni, "Private Divorces" and Islamic law under the Rome III Regulation”, The European Legal Forum, vol. 3/4, 2017, pp. 68-74.

${ }^{128}$ Apartado 39.

${ }^{129}$ S. Álvarez GonzÁlez, “Sahyouni. Más allá del espejo...”, loc.cit., p. 19.

${ }^{130} \mathrm{Vid}$. en https://juris.bundesgerichtshof.de/cgi-bin/rechtsprechung/document.py?Gericht=bgh\&Art=en\&sid=898fb3f34a 
dieron lugar al caso Sahyouni-. Para dicho tribunal, aunque el art. 10 del Reglamento Roma III no sea aplicable ${ }^{131}$, a tenor de lo dispuesto en el art. 6 del EGBGB ${ }^{132}$, podría denegarse el reconocimiento de tales divorcios. Para ello, sería preciso analizar los resultados a los que se llega con la aplicación la lex causae y ver hasta qué punto se violan (o no) los principios y valores fundamentales del sistema legal alemán. Téngase, por ejemplo, en cuenta que, en Alemania, los divorcios mediante declaraciones unilaterales (como talaq o ghet) no violan el orden público alemán, si ambos cónyuges están de acuerdo en el divorcio. Para este tribunal, era evidente que, en este caso, en concreto, la esposa no deseaba el divorcio, por lo que consideró que no era factible su reconocimiento en Alemania por violar su orden público. En la jurisprudencia española hay abundantes ejemplos de cuándo este tipo de divorcios vulneran (o no) el orden público español, por lo que la respuesta a esta cuestión no puede ser ni definitiva ni concluyente. Dependerá de las circunstancias de cada caso en concreto.

\section{B) ¿Puede el divorcio contractual francés ser reconocido en España?}

43. De la misma manera, cabe preguntarse si el "divorcio privado" admitido en Derecho francés sería reconocido (o no) por las autoridades españolas ${ }^{133}$. Téngase en cuenta que se trata de un divorcio "desjudicializado" 134 y "contractualizado", y que en su regulación legal no existe previsión alguna ni sobre la competencia interna ni internacional, lo que lo convierte en un "divorcio sin foro" 135.

Se trata de un divorcio en el que la intervención del notario es mínima. Se limita a recibir el acuerdo al que llegan las partes en presencia de su abogado. El principal problema que plantea en la práctica este tipo de divorcios el de su eficacia extraterritorial en otros Estados ${ }^{136}$. Cabe preguntarse, por tanto, si el divorcio contractual francés podría ser reconocido en España. A priori, podría pensarse que, en la medida en que el acuerdo de divorcio es autorizado por un notario francés, podría serle de aplicación el sistema del reconocimiento previsto en el RBr II bis. No obstante, a nuestro juicio, ello no resultaría factible, puesto que el documento en el que se declara el divorcio no merece el calificativo de "resolución judicial", tal y como se define en el art. $2.4^{\circ}$ del $\mathrm{RBr}$ II bis en relación con el art. $2.1^{\circ}$ de dicho Texto normativo.

44. Queda la cuestión de saber, si este tipo de divorcios podrían ser reconocidos en España a partir de lo establecido en el art. $46 \mathrm{RBr}$ II bis, como así se ha planteado la doctrina francesa ${ }^{137}$. Dicha

a99ec390559632aec5d33e\&nr=110810\&pos=0\&anz=1\&Blank=1.pdf

${ }^{131}$ Sobre la interpretación de este precepto vid. la reciente Sent. del TJCE de 16 de julio de 2020 (As. C-249/19). Un comentario en P. DIAGO DIAGO, "Cuando la ley aplicable no contemple el divorcio se aplicará la ley del foro: interpretación restrictiva del art. 10 del Reglamento 1259/2010 proporcionada por la STJUE de 16 de julio de 2020 asunto C-249/19”, La Ley. Unión Europea, $\mathrm{n}^{\circ}$ 85, 2020, pp. 1-10.

132 "A provision of the law of another country shall not be applied where its application would lead to a result which is manifestly incompatible with the fundamental principles of German law. In particular, inapplicability ensues, if its application would be incompatible with civil rights" (https://www.gesetze-im-internet.de/englisch_bgbeg/englisch_bgbeg.html\#p0042).

${ }^{133}$ Introducido por la Loi núm. 2019-222 de 23 marzo de 2019 de programmation 2018-2022 et de réforme pour la justice extiende la normativa prevista para el divorcio privado a la separación (art. 298 Código civil francés). [https://www.legifrance. gouv.fr/affichTexte.do?cidTexte=JORFTEXT000038261631\&categorieLien=id]

${ }^{134}$ A. Devers, "Le divorce sans juge en droit international privé", Droit de la Famille, 2017, vol. 5, p. 1.

${ }^{135}$ P. HaмmJe, "Le divorces par consentement mutuel extrajudiciaire et le droit international privé. Les aléas d'un divorce sans fore", Rev.crit.dr.int.pr., 2017, p. 143.

${ }^{136}$ En la jurisprudencia comparada encontramos decisiones que han rechazado el reconocimiento de este tipo de divorcios, como así ocurrió en las Sents. dictadas por el Tribunal de Sidi M'Hamed, de 26 septiembre de 2017 y por el Tribunal de primera instancia d'Oujda, de 29 de enero de 2018. Por el contrario, su reconocimiento fue aceptado en la decisión adoptada por el Tribunal de primera instancia de Túnez, de 14 de noviembre de 2017 (vid. s. BEN ACHOUR, "Le divorce extrajudiciaire franÇais devan le jueg tunisien, una tolérance a contrecoeur", Rev.crit.dr.int.pr., 2017, pp. 211-227; M. LAMARCHE, “Orgueil et préjugés: le sort du divorce sans juge au sud de la Méditerranée”, La Semaine Juridique, notariale et immobilière, 2018, pp. 7-8; M. EL BAHJA, "Le Maroc et le divorce par consentement mutuel français", La Semaine Juridique, notariale et immobilière, 2018, pp. 7-8). En Marruecos, el Gobierno marroquí promulgó el 18 de febrero de 2019 una Circular en la que se manifestaba a favor del reconocimiento de este tipo de divorcios en Marruecos. No es preciso obtener el execuátur del mismo y será reconocido, siempre que no se vulnere el orden público marroquí en https://www.labase-lextenso.fr/gazette-du-palais/GPL347k9.

${ }^{137}$ P. HАMmJE, "Le divorces par consentement mutuel...", loc.cit., p. 143; S. Ben Achour, "Le divorce...,, loc.cit., p. 213. 
norma permite que un documento público con fuerza ejecutiva formalizado en un Estado miembro, así como los acuerdos entre las partes que tengan fuerza ejecutiva en el Estado miembro de origen, pueda ser reconocido y se le dote de dicha fuerza en las mismas condiciones que las resoluciones judiciales. Una opción que, a nuestro juicio, no resulta operativa, siguiendo a P. Hammje, puesto que resulta dudoso que un divorcio contractual francés constituya un acto susceptible de ejecución ${ }^{138}$.

A nuestro juicio, dicho Reglamento no sería aplicable al reconocimiento de tales divorcios en nuestro país. Por ello, sorprende que el legislador francés admitiera dicha posibilidad en la Circular 19 del Ministerio de Justicia de 26 de enero de 2017 (Ficha 10 $\left.0^{139}\right)^{140}$. En esta disposición el legislador francés habilitó a los notarios franceses como autoridades competentes para expedir el certificado al que el art. 39 del RBr II bis hace referencia ${ }^{141}$. A nuestro juicio, resulta cuestionable y criticable ${ }^{142}$ que por una vía tan poco ortodoxa se permita la aplicación del RBr II bis para el reconocimiento de tales divorcios en España. No obstante, dicha habilitación facilita, sin duda alguna, la circulación de tipo de divorcios en todos los Estados miembros del Reglamento y, por ende, también en nuestro país. Resulta preciso saber, por tanto, si este tipo de divorcio sería reconocido (o no) en España. Como se ha evidenciado, la eficacia de este tipo de divorcios estaría sometida a un número muy reducido de controles. Solo la vulneración de nuestro orden público internacional [art. 22 a)] o la inconciabilidad con otra decisión [art. 22 c y d)] serían los únicos motivos por los que se podrían impedir su reconocimiento en nuestro país. Y no siempre, puesto que el concepto de orden público y de incompatibilidad que deben ser aplicados por parte de las autoridades españolas es el establecido en el Reglamento europeo. No puede ser desvirtuado, por tanto, por categorías y conceptos internos. Además, no hay que olvidar que el control de estas condiciones está sometido a ciertos límites en el propio Reglamento. Así, por ejemplo, el control de orden público en dicho Texto normativo no permite introducir ni un control de competencia -aunque hubiera existido fraude en la búsqueda del foro- (art. $24 \mathrm{RBr}$ II bis) ni de ley aplicable (art. $25 \mathrm{RBr}$ II bis). Así pues, al reducirse considerablemente los controles a realizar sobre tales divorcios, se elevan exponencialmente las posibilidades de su reconocimiento en España.

45. Una praxis que resulta ciertamente preocupante, y que va a perpetuarse con el $\mathrm{RBr}$ II bis refundido, puesto que, según dicho Reglamento, los documentos públicos y los acuerdos entre partes relativos al divorcio que tengan efecto jurídico vinculante en un Estado miembro deben asimilarse a «resoluciones» a efectos de la aplicación de las normas sobre reconocimiento (Considerando 70). El presente Reglamento no autoriza la libre circulación de acuerdos meramente privados, pero sí de cualquier acuerdo que adquiera efecto jurídico vinculante en el Estado miembro de origen tras la intervención formal de una autoridad pública (Considerando 14). El Reglamento posibilita, así, el reconocimiento de este tipo de divorcios entre los Estados miembros a partir de lo establecido en los arts. 64 y $65.1^{\text {o143 }}$. El primero de ellos establece que la sección 4 del Reglamento, titulada de "Documentos públicos y acuerdos", resulta aplicable en materia de divorcio a los documentos públicos que hayan sido formalizados o registrados, y a los acuerdos que hayan sido registrados en un Estado miembro que ejerza su competencia con arreglo al Capítulo II. Se autoriza la circulación de los acuerdos en materia de divorcio, siempre que vayan acompañados del correspondiente certificado ${ }^{144}$, Dicho precepto exige además que dicho Estado debe ejercer su competencia con arreglo al Capítulo II, capítulo donde se contemplan las

\footnotetext{
${ }^{138}$ P. Hammje. "Le divorces par consentement mutuel...", loc.cit., p. 143.

${ }^{139}$ BOMJ núm. 2, 2017-06, du 30 juin 2017.

${ }^{140}$ Esta previsión normativa fue dictada por el legislador francés junto al Décret $\mathrm{n}^{\circ}$ 2016-1907 de 28 diciembre de 2016 por el que derogaba lo establecido en el art. 509-3 del Código de Procedimiento Civil- para resolver las dudas y los problemas que suscitaban este tipo de divorcios en Francia (JORF n 0302 du 29 décembre 2016).

${ }^{141}$ Ello explica que un grupo de juristas, encabezado por el profesor Nourissat, interpusiera un recurso contra Francia por el incumplimiento del Derecho europeo y, en particular, de los Reglamentos Bruselas II bis y Roma III (https://www. notariatresguerres.es/la-circulacion-en-europa-del-divorcio-notarial/).

${ }^{142}$ E. vVGanotti, "Rome III et le divorce sans juge", Gazette du Palais, no 7, de 20 de febrero de 2018, p. 27.

${ }^{143}$ S. Corneloup/ T. Kruger, "Le Règlement 2019/1111, Bruxelles II: la protection des enfants gagne du ter(rain)", Rev.crit. drint.pr, 2020-2, pp. 215-245.

${ }^{144}$ Según el art. 100 del nuevo Reglamento, este régimen de reconocimiento será aplicable solo a los documentos públicos formalizados o registrados y a los acuerdos registrados el 1 de agosto de 2022 o después de esa fecha.
} 
normas de competencia internacional. De la lectura de este precepto parece deducirse que el legislador europeo condiciona la eficacia de tales divorcios a que tales acuerdos sean registrados por autoridades con competencia internacional, según lo establecido en los arts. 3 al 6 del Reglamento.

Por su parte, el art. $65.1^{\circ}$ del Reglamento establece la posibilidad de obtener el reconocimiento automático de aquellos documentos públicos y los acuerdos sobre divorcio que tengan efecto jurídico vinculante en el Estado miembro de origen. En particular, se reconocerán en otro Estado miembro sin que se requiera ningún procedimiento especial aplicándose las normas previstas para el reconocimiento y la ejecución de decisiones judiciales extranjeras (Capítulo IV), salvo disposición en contrario. El control que se podrá ejercer sobre este tipo de divorcios será de mínimos (art. 38). Desde la perspectiva española, la consecuencia más importante que se deriva de esta regulación es que el reconocimiento del divorcio contractual francés solo podría ser denegado en España si se vulnerara el orden público español [art. 38 a)] o resultara inconciliable con otra decisión dictada en España u otro Estado [art. 38 b)].

46. Con todo, aun en el caso de que fuera operativa la cláusula de orden público ${ }^{145}$, sería oportuno saber hasta qué punto la necesidad de dotar de continuidad al estado civil de las personas, como así argumentó la Sent. dictada por el Tribunal de Primera instancia de Túnez el 14 de noviembre de 2017, o el Derecho al respeto a la vida privada de la familia (ex art. 8 Convenio para la Protección de los Derechos Humanos y de las Libertades Fundamentales, hecho en Roma el 4 de noviembre de $\left.1950^{146}\right)^{147}$, según ha dispuesto el Tribunal Europeo de Derechos Humanos en la Sent. dictada en el caso Wagner y J.M.W.L contra Luxemburgo, el 28 de junio de $2007^{148}$, podrían constituir argumentos de peso a tener en cuenta para que este tipo de divorcios pudieran ser reconocidos en nuestro país ${ }^{149}$. Unos argumentos que, a pesar de su bondad, revisten, a nuestro juicio, una vertiente tan excesiva como peligrosa, puesto que fuerzan a los Estados a abrir sus sistemas de DIPr. con el objeto de reconocer una relación familiar constituida válidamente en el extranjero ex. lex causae, incluso, cuando aquella no respetara la legalidad vigente en el Estado en el que se pretende su eficacia. No obstante, esta es una incógnita que solo podrá ser despejada por la práctica jurisprudencial en los años venideros. Con todo, la posibilidad que existe, como hemos advertido, de que tales divorcios circulen libremente entre los Estados miembros evidencia los excesos y los peligros a los que conduce tanto el principio de confianza europea, como la idea pro reconocimiento que se está expandiendo en los últimos tiempos en las relaciones familiares ${ }^{150}$.

\section{Efectos de las cuestiones accesorias a la disolución del matrimonio}

\section{Liquidación de régimen económico matrimonial}

47. El reconocimiento de la liquidación del régimen económico de un matrimonio disuelto por autoridad no judicial extranjera presenta una relevancia singular, pues la suerte misma del divorcio, puede depender de que exista una efectiva liquidación del régimen económico matrimonial. Determinar el régimen de reconocimiento de las decisiones en este ámbito constituye una cuestión compleja. No solo por la pluralidad de fuentes normativas (institucional, convencional y estatal) existentes en nuestro sistema jurídico, sino también porque, como hemos apuntado, el concepto de "resolución judicial" que

\footnotetext{
${ }^{145}$ R. Arenas García, Crisis matrimoniales..., op.cit., p. 401.

${ }^{146}$ BOE de 10 de octubre de 1979.

${ }^{147}$ S. Ben Achour, "Le divorce...”, loc.cit., p. 226.

148 Aranzadi Westlaw JUR 2007, 147388. En esta sentencia, dicho Tribunal consideró que un Estado no debe denegar el reconocimiento de una adopción válidamente constituida en el extranjero, cuyos vínculos familiares se han consolidado, por considerar que la misma no reúne los requisitos legales para su reconocimiento, en la medida en que ello vulnera varios derechos establecidos en el CEDH. La Sent. del TEDH de 3 de mayo de 2011 aplicó una doctrina similar respeto de las restricciones del legislador griego frente a las adopciones por religiosos o monjes.

${ }^{149}$ S. Ben Achour, "Le divorce...", loc.cit., p. 226.

${ }^{150}$ N. Marchal Escalona, “La adopción internacional y otras formas de protección del menor”, en m.C. García GarniCA, N. MARChAl ESCALONA (DIR.), G. MORENO CORDERO, A. QUESADA PÁEZ (Coords.), Aproximación interdisciplinar a los retos actuales de protección de la infancia dentro y fuera de la familia, Navarra, Aranzadi, 2019, pp. 718-719.
} 
emplean estas normas difieren de una a otra norma. A ello hay que añadir, que la liquidación de dicho régimen puede haber sido determinada $\mathrm{y}$, por tanto, constar en el mismo documento y de forma conjunta a la disolución de dicho matrimonio (Cuba, Brasil, Colombia, Rumanía, Portugal, Italia, Dinamarca y Noruega), en otra escritura pública otorgada de forma independiente y previa a la disolución del mismo, como así exigen algunos Estados para acceder a este tipo de divorcios (Letonia, Estonia, México, Bolivia, Nicaragua y Perú), haber sido concretada en capitulaciones matrimoniales otorgadas previamente, o bien en una posterior decisión judicial, como así ocurre en Rusia, Moldavia y Armenia.

48. En Derecho español, las reglas de reconocimiento de resoluciones judiciales y documentos públicos extranjeros sobre liquidación de matrimonio se encuentran recogidas tanto en el Reglamento (UE) n $n^{\circ} 2016 / 1103$ del Consejo de 24 de junio de 2016 por el que se establece una cooperación reforzada en el ámbito de la competencia, la ley aplicable, el reconocimiento y la ejecución de resoluciones en materia de regímenes económicos matrimoniales (en adelante, Reglamento $\mathrm{n}^{\mathrm{o}}$ 2016/1103 ${ }^{151}$ ) -que entró en vigor el 29 de enero de 2019-, así como en diversos convenios bilaterales en los que España forma parte y en la normativa estatal.

En particular, el Reglamento $n^{\circ}$ 2016/1103 se aplica a aquellas "resoluciones judiciales" o a aquellos "documentos públicos" procedentes de otro Estados miembros del Reglamento en el ámbito de aplicación del mismo. Dicho Reglamento reemplaza en las relaciones entre los Estados miembros a los convenios internacionales en vigor (art. 62.2 $2^{\circ}$ ), aunque subsisten frente a terceros Estados $\left(\operatorname{art} .62 .1^{\circ}\right.$ ). Fuera del ámbito internacional será de aplicación el régimen estatal dentro del cual cabe cifrar tanto la LJV como la LCJIMC y la LEC. Saber cuándo se aplica una u otra disposición normativa dependerá de cuál sea el efecto pretendido (probatorio, registral o ejecutivo), de la función que hubiera desempeñado la autoridad no judicial extranjera, así como de cuál sea el documento en el que se liquide el régimen económico, cuyo reconocimiento se pretende (escritura pública de divorcio, escritura pública de liquidación, capitulaciones matrimoniales o sentencia judicial).

49. Concretar, pues, cuál es el régimen jurídico de reconocimiento aplicable a la liquidación del régimen económico de un matrimonio disuelto por autoridad no judicial dependerá no solo del país de donde proceda dicha liquidación, de la fecha en la que esta se haya producido, sino también del efecto que se pretenda obtener con su reconocimiento (probatorio, registral o ejecutivo). Pero, fundamentalmente, lo que determinará el régimen aplicable al reconocimiento de dicha liquidación es si esta tiene lugar (o no) junto a la disolución del matrimonio. Y de ser así, de la función que hubiera desempeñado la autoridad que hubiera procedido a disolver el matrimonio y, en concreto, de si equivale (o no) a la que desempeñan las autoridades judiciales españolas.

50. El Reglamento $n^{\circ} 2016 / 1103$ garantiza la eficacia de la liquidación matrimonial obtenida ante las autoridades de otro Estado miembro del Reglamento. Ahora bien, la cuestión que se plantea de inmediato es la saber si dicho Texto es aplicable al reconocimiento de la liquidación del régimen económico de un matrimonio disuelto por una autoridad no judicial procedente de Italia y Portugal, en la medida en que ambos Estados forman parte de dicho Reglamento. La posibilidad de aplicar dicha norma dependerá de dos factores. Por una parte, de si tales decisiones pueden ser consideradas (o no) como "resolución judicial", según el concepto que dicho Texto incorpora. Y, por otra, de si dicha liquidación tiene lugar antes o de forma conjunta a la disolución del matrimonio

Para este Reglamento, resolución es:

"cualquier resolución en materia de régimen económico matrimonial dictada por un órgano jurisdiccional de un Estado miembro con independencia de la denominación que reciba, incluida una resolución sobre la determinación de las costas o gastos por parte de un funcionario judicial" [art. 3.1 ${ }^{\circ} \mathrm{d}$ )].

${ }^{151}$ DOUE 183 de 8 de julio de 2016, p.1. 
Este precepto relaciona e identifica el concepto de "resolución judicial" con el de "órgano jurisdiccional" (art. $\left.3 \cdot 2^{\circ}\right)$. A tenor del cual:

"toda autoridad judicial y todas las demás autoridades y profesionales del Derecho con competencias en materia de regímenes económicos matrimoniales y que ejerzan funciones jurisdiccionales o que actúen por delegación de poderes de una autoridad judicial o bajo su control, siempre que dichas otras autoridades y profesionales del Derecho ofrezcan garantías en lo que respecta a su imparcialidad y al derecho de todas las partes a ser oidas, y que sus resoluciones, adoptadas con arreglo al Derecho del Estado miembro en el que actúan: a) puedan ser objeto de recurso o revisión ante la autoridad judicial) tengan una fuerza y unos efectos similares a los de la resolución de una autoridad judicial sobre la misma materia".

Este Reglamento para saber si puede ser aplicado (o no) por autoridades no judiciales y, por tanto, para ser aplicado al reconocimiento de las decisiones adoptadas por aquellas, reproduce el modelo del Reglamento de sucesiones ${ }^{152}$. Sus Considerandos 29 y 20 replican, como así ha evidenciado P. Jiménez Blanco, el esquema de equivalencia entre "función jurisdiccional" y sometimiento a los "criterios de competencia del Reglamento" 153 . Además de seguir el sistema del listado remitido por cada Estado. De manera que, según la declaración realizada por el Gobierno italiano, los funcionarios del Registro Civil (Ufficiali di Stato Civile) son considerados como autoridades competentes para aplicar lo dispuesto en el Reglamento cuando ejerzan sus funciones en el marco del art. 12 del Decreto Ley $n^{\circ}$. 132/2014 ${ }^{154}$. La consecuencia que se deriva de dicha declaración es que las disposiciones de dicho Reglamento podrían ser aplicables al reconocimiento de aquellas decisiones en las que se liquide el régimen económico matrimonial de un matrimonio disuelto por dicha autoridad. Con todo, no hay que olvidar que, la liquidación del mismo debe de ser concertado antes en un documento público de forma independiente o en unas capitulaciones matrimoniales. Por consiguiente, su reconocimiento deberá seguir el régimen dispuesto en el Reglamento para los documentos públicos extranjeros ${ }^{155} \mathrm{y}$, particularmente, lo dispuesto en su art. 58, si lo que se pretende es su eficacia probatoria (art. $58^{156}$ ) y al art. $59^{157}$, si es ejecutiva. Pero, si lo que se pretendiera fuera su eficacia registral, se estaría a lo dispuesto en el ar. 60 LCJIMC $^{158}$ al ser una cuestión no regulada en dicho Reglamento.

${ }^{152}$ Reglamento (UE) no 650/2012 del Parlamento Europeo y del Consejo, de 4 de julio de 2012, relativo a la competencia, la ley aplicable, el reconocimiento y la ejecución de las resoluciones, a la aceptación y la ejecución de los documentos públicos en materia de sucesiones mortis causa y a la creación de un certificado sucesorio europeo (DOUE de 27 de julio de 2012, p. 107).

${ }^{153}$ Id. "Concepto de "órgano jurisdiccional”. ..., loc.cit., p. 155.

$154 \mathrm{https}$ ://e-justice.europa.eu/content_matters_of_matrimonial_property_regimes-559-it-es.do?member=1.

${ }^{155}$ Por documento público se entiende todo "documento en materia de régimen económico matrimonial que ha sido formalizado o registrado como documento público en un Estado miembro y cuya autenticidad: i) se refiere a la firma y al contenido del documento público, y ii) ha sido establecida por una autoridad pública u otra autoridad facultada a tal fin por el Estado miembro de origen";

${ }^{156}$ De manera que, aquellos documentos expedidos en un Estado miembro tendrán en otro Estado miembro el mismo valor probatorio -o el efecto más parecido posible- que en el primero, siempre que ello no sea manifiestamente contrario al orden público del segundo (art. 58.1 $1^{\circ}$ ). Para articularlo se establecen las posibilidades de: a) solicitar el formulario al que se refiere el art. $67.2^{\circ}$ especificando el valor probatorio del documento ab origine (art. $58.1^{\circ}$ in fine); b) recurrir la autenticidad del documento público, lo que ha de hacerse ante las autoridades del Estado donde fue formalizado y conforme a su legislación, considerandos 59 y 58 in fine, respectivamente; y c) recurrir asimismo los actos o relaciones jurídicos consignados en el documento público en cuestión (para lo que se aplicarían las normas sobre competencia y Ley aplicable consagradas en los propios Reglamentos). La interposición de ambos tipos de recursos priva a los documentos públicos de su valor probatorio (art. $58.2^{\circ}$ y $3^{\circ}$, y Considerandos 62 y 61 , respectivamente). Al respecto, vid. A. RODRíGUEZ BENOT, "Los efectos patrimoniales de los matrimonios y de las uniones registradas en la Unión Europea", CDT, Vol. 11, n 1, 2019, pp. 8-50.

${ }^{157}$ Se consideran como tales a: "Los documentos públicos que tengan fuerza ejecutiva en el Estado miembro de origen serán declarados, a instancia de cualquiera de las partes, documentos con fuerza ejecutiva en otro Estado miembro de conformidad con el procedimiento previsto en los artículos 44 a 57 ".

${ }^{158}$ Según el mismo: "Los documentos públicos extranjeros extrajudiciales podrán ser inscritos en los registros públicos españoles si cumplen los requisitos establecidos en la legislación especifica aplicable y siempre que la autoridad extranjera haya intervenido en la confección del documento desarrollando funciones equivalentes a las que desempeñan las autoridades españolas en la materia de que se trate y surta los mismos o más próximos efectos en el país de origen". 
Por su parte, Portugal ha designado a los Encargados del Registro Civil como autoridades competentes a efectos de aplicar las disposiciones del Reglamento ${ }^{159}$, por lo que el reconocimiento de la decisión de liquidación matrimonial realizada por acuerdo de los cónyuges ante dicha autoridad, seguirá el régimen aplicable a las resoluciones judiciales (arts. 36-57) en dicho instrumento normativo. En consecuencia, sería posible obtener tanto su reconocimiento automático (art. $36.1^{\circ}$ ) como su eficacia ejecutiva (art. 49), según el efecto pretendido por las partes, siendo controladas las condiciones de denegación de reconocimiento previstas en el art. 37. No cabría realizar control de competencia (art. 39).

51. En defecto de norma institucional aplicable, el reconocimiento de una decisión de liquidación del régimen económico de un matrimonio disuelto por autoridad no judicial extranjera podrá surtir efectos en nuestro país con arreglo a lo establecido en los Tratados y convenios internacionales de los que España forma parte. Estos serán de aplicación, siempre que su ámbito de aplicación material lo permita y el concepto de "resolución" que prevea sea lo suficiente amplio como para incluir las decisiones adoptadas por autoridades no judiciales. De hecho, el análisis de los convenios bilaterales suscritos por España con aquellos países que contemplan el divorcio no judicial, nos permite concluir su escasa operatividad práctica. En unos casos, porque la liquidación del régimen económico del matrimonio constituye una materia que está excluida de su ámbito de aplicación material ( $a d$ ex. convenio hispanobrasileño e hispano-mexicano) y, en otros, porque solo se aplica al reconocimiento de "resoluciones judiciales" entendiendo por tales aquellas procedentes de órganos jurisdiccionales, como así ocurre con el Convenio hispano-chino (art. 16.3 ${ }^{\circ}$ y el hispano-colombiano (art. 1).

Mención especial merece el convenio hispano-ruso que resultará aplicable al reconocimiento de aquellas resoluciones judiciales en las que se proceda a liquidar el régimen económico matrimonial dictadas tras la disolución no judicial del matrimonio ex art. 20 Family Code of the Russian Federation. A tenor de dicho Convenio, cabe solicitar tanto el reconocimiento automático (art. 24.1 ${ }^{\circ}$ ) como el execuátur (art. 22), según el efecto pretendido por las partes, siendo controladas las condiciones de denegación de reconocimiento previstas en los arts. 18 y 19.

52. Ahora bien, para saber cómo se reconoce la liquidación del régimen económico de un matrimonio disuelto por autoridad no judicial extranjera en defecto de norma institucional y convencional aplicable, hay que distinguir si esta se produce conjuntamente con la disolución del matrimonio, en un documento distinto y previo al mismo o en virtud de una decisión judicial posterior a su disolución. En el primer supuesto, habría que estar, a su vez, tanto al efecto pretendido como a la función desempeñada por la autoridad no judicial al disolver el matrimonio. Así, si esta es equivalente a la función que desempeñan las autoridades judiciales, la norma aplicable a su reconocimiento, así como las condiciones de reconocimiento a controlar por las autoridades españolas serían ex art. $11.3^{\circ}$ las establecidas en el art. 11 LJV, si el efecto pretendido fuera el registral; mientras que, si el efecto pretendido fuera el ejecutivo, sería de aplicación lo dispuesto en la LCJIMC (art. 50), y los arts. $323.2^{\circ}$ y 144 LEC si fuera el probatorio. Por el contrario, si dicha autoridad no desempeñara funciones equivalentes a las que ejercita la autoridad judicial española cuando interviene, es decir, la decisión extranjera no fuera equivalente a la resolución judicial, se debería de estar a lo establecido en LCJIMC, si el efecto pretendido fuera el efecto ejecutivo (art. 56), a los arts. $323.2^{\circ}$ y 144 LEC si fuera el efecto probatorio y a la Disposición adicional tercera de la LJV si fuera el registral.

En el tercer y último lugar, es decir, si la liquidación del régimen económico del matrimonio tiene lugar con posterioridad a la disolución del matrimonio vía judicial (ad ex. Armenia), en tales casos, el reconocimiento de dicha resolución seguiría el régimen establecido por la LCJIMC, salvo las procedentes de Rusia que serían reconocidas, como hemos visto, según lo establecido en el Convenio bilateral suscrito con dicho país.

53. Mención especial merece saber qué sucede cuando el régimen económico matrimonial se liquida tras un divorcio privado obtenido en Francia, donde el procedimiento de liquidación del régimen

${ }^{159} \mathrm{https}$ ://e-justice.europa.eu/content_matters_of_matrimonial_property_regimes-559-pt-es.do?clang=fr 
matrimonial debe tener lugar antes del divorcio. De hecho, ambos cónyuges deben incluir en el acuerdo de divorcio la declaración de liquidación ${ }^{160}$. En particular, esta declaración de liquidación debe ser establecida por un notario si hay bienes sujetos a publicidad ex 229-3.5. ${ }^{\circ}$ Code ${ }^{161}$. De forma que el régimen jurídico aplicable a su reconocimiento en España podría variar, según si dicha liquidación tiene lugar vía notarial o judicial.

\section{Obligaciones alimenticias}

54. Saber cómo se reconoce en España una pensión alimenticia obtenida tras la disolución de un matrimonio dictada por autoridad no judicial que, según el análisis de Derecho comparado llevado a cabo, puede afectar solo al excónyuge o incluir igualmente a los hijos, constituye una cuestión eminentemente compleja. No solo por la pluralidad de fuentes normativas (institucional, convencional y estatal) existentes en el sistema jurídico español y las diferentes nociones que cada texto incorpora de la noción "resolución" a los efectos de su aplicación, sino también porque dicha decisión puede haber sido pronunciada junto con la disolución del matrimonio, o bien posteriormente vía judicial una vez disuelto el matrimonio, como así sucede en Rusia y Armenia.

Para determinar el régimen aplicable al reconocimiento de una obligación alimenticia decretada por autoridad no judicial extranjera tras la disolución de un matrimonio habrá que estar al país donde se ha acordado dicha obligación, a la fecha en la que esta se haya obtenido, pero, sobre todo a la función que hubiera desempeñado la autoridad que hubiera procedido a disolver el matrimonio y, en concreto, si dicha función equivale a la que ejercitan las autoridades judiciales españolas cuando disuelven el vínculo matrimonial, como así sucede en Cuba, Colombia, Noruega, Dinamarca, Rumania, Estonia, Moldavia, Portugal, China, y Japón, o si, por el contrario, esta equivalencia no tiene lugar, como así ocurre en México, Brasil, Educador, Perú, Bolivia, Nicaragua, Letonia, Ucrania, Italia y Kirguistán.

En Derecho español, la pluralidad de fuentes institucionales, convencionales y estatales existentes en el sistema jurídico convierte la identificación del régimen jurídico aplicable al reconocimiento de una decisión judicial extranjera dictada en materia de alimentos en una cuestión tan esencial como compleja. Esta confluencia de regímenes obliga a articular las relaciones entre todos ellos. Saber qué instrumento se aplica requiere, por una parte, delimitar con precisión el ámbito de aplicación de cada Texto normativo (material, espacial y temporal) y, por otra, estar a lo dispuesto en los propios instrumentos legales sobre su prevalencia sobre otros (cláusulas de relación o de compatibilidad). El alcance de esta compatibilidad depende, pues, del análisis y la comparación de los diferentes instrumentos jurídicos, teniendo en cuenta que en este ámbito destaca, de forma muy especial, la aplicación de la norma más favorable (favor executionis). Esta regla de delimitación es particularmente operativa en materia alimenticia. De hecho, como tendremos oportunidad de analizar, algunos textos convencionales exceptúan expresamente su aplicación en favor no solo de otros instrumentos internacionales, sino también del propio régimen común ${ }^{162}$. Con todo, es preciso saber que esta regla no habilita la aplicación de los distintos Convenios en forma de mosaico ${ }^{163}$.

55. En el ámbito europeo la norma clave para el reconocimiento de decisiones dictadas en materia alimenticia es el Reglamento (CE) n ${ }^{\circ}$ 4/2009 del Consejo, de 18 de diciembre de 2008, relativo a la competencia, la ley aplicable, el reconocimiento y la ejecución de las resoluciones y la cooperación en materia de obligaciones de alimentos (en adelante RB-III). La cuestión está en saber si dicho Reglamento puede aplicarse o no para reconocer aquellas decisiones alimenticias dictadas tras la disolución no judicial de un matrimonio obtenido en Letonia, Rumania, Estonia, Portugal e Italia. Todo depende

\footnotetext{
${ }^{160} \mathrm{https}$ ://www.jurifiable.com/conseil-juridique/droit-de-la-famille/liquidation-regime-matrimonial.

161 "L'état liquidatif du régime matrimonial, le cas échéant en la forme authentique devant notaire lorsque la liquidation porte sur des biens soumis à publicité foncière, ou la déclaration qu'il n'y a pas lieu à liquidation".

162 J.C. FeRnÁnDEZ ROZAS, S.A. SÁNCHEZ LORENZO, Derecho internacional ..., op.cit. p. 404.

163 A.l. calvo Caravaca, J. Carrascosa González, Derecho internacional..., op.cit., p. 564.
} 
de si tales decisiones pueden ser o no consideradas como "resoluciones judiciales" a efectos de su aplicación. Este Reglamento se aplica al reconocimiento de "resoluciones judiciales extranjeras" (art. 2.1 ${ }^{\circ}$ ) entendiendo por tales las dictadas por órganos jurisdiccionales incluyendo dicha definición a las autoridades administrativas (art. 2.2 $2^{\circ}$ ). Para identificar a estas últimas, se sigue el sistema de listado ${ }^{164}$. A tenor de dicho concepto y de dicho listado, cabe concluir que las decisiones de alimentos obtenidas tras la disolución no judicial de un matrimonio en tales países no podrían ser reconocidas como "resoluciones judiciales extranjeras" (arts. 16-22), porque no merecen dicho calificativo. Por el contrario, sí podrían serlo como documentos públicos ex art. $2.1^{\circ} .3^{\circ}$ y obtener fuerza ejecutiva en nuestro país a partir de lo previsto para las resoluciones judiciales ( $e x$ art. 48), siempre que tales decisiones pudieran ser consideradas como «documento público con fuerza ejecutiva», tal y como el propio Reglamento establece ${ }^{165}$.

A su vez, el RB-III prevalece sobre el Reglamento (CE) no 805/2004 del Parlamento Europeo y del Consejo, de 21 de abril de 2004, por el que se establece un título ejecutivo europeo para créditos no impugnados (en adelante RTEE ${ }^{166}$ ) -art. $68.2^{\circ}-$, así como sobre el Convenio de Lugano de 30 de octubre de 2007 relativo a la competencia judicial y a la ejecución de resoluciones judiciales en materia civil y mercantil (en adelante CL II) ${ }^{167}$. Este convenio será aplicable al reconocimiento de aquellas decisiones adoptadas en materia alimenticia tras la disolución de un matrimonio acordado por autoridades no judiciales noruegas y danesas. Ahora bien, no resultarían de aplicación las disposiciones relativas al reconocimiento de "resoluciones judiciales" (Título III) por cuanto el concepto que incorpora este instrumento normativo es muy restringido, pues solo afecta a resoluciones dictadas por tribunales judiciales (art. 32). En cambio, sí lo serían aquellas relativas al reconocimiento de documentos públicos (art. 57). Este Convenio resulta compatible con el Convenio de La Haya de 23 de septiembre de 2007 sobre cobro internacional de alimentos para los niños y otros miembros de la familia (en adelante $\mathrm{CH} 2007)^{168}$, que ha sustituido entre los Estados partes a otros Convenios de la Conferencia de La Haya -art. 61 CL II-.

56. Por su parte, en el ámbito convencional hallamos una serie de Convenios (multilaterales y bilaterales) que son de aplicación, siempre que su ámbito de aplicación (material, espacial y temporal) lo permita, y no hayan sido desplazados ni por el RB-III (art. 69) ni por ningún otro instrumento normativo.

En particular, el régimen convencional multilateral se cifra en un nutrido cuerpo normativo. En primer término, y en el marco de la Conferencia de La Haya, cabe destacar al CH 2007. Este Convenio ha sustituido en las relaciones entre los Estados partes tanto al Convenio referente al reconocimiento y a la ejecución de las resoluciones relativas a las obligaciones alimenticias, hecho en La Haya el 2 de octubre de $1973^{169}$ (en adelante CH 1973), así como al Convenio de La Haya de 15 de abril de 1958, relativo al reconocimiento y a la ejecución de las decisiones en materia de obligaciones alimenticias para con los hijos (en adelante $\mathrm{CH} 1958)^{170}$, en la medida en que su ámbito de aplicación coincida (ex art. $48 \mathrm{CH}$ 2007), salvo lo dispuesto en el art. $56.2^{\circ} \mathrm{CH} 2007$. No obstante, esta regla de prevalencia no implica el desplazamiento total de los instrumentos internacionales y estatales que regulan esta materia por cuanto el CH 2007 permite el recurso a otros instrumentos normativos -convencionales y estatales- si estos resultan más favorables (art. 52). A tenor de dicha regla, debe darse aplicación preferente al instrumento legal que favorezca en mayor medida la eficacia extraterritorial de decisiones en materia de alimentos (eficacia máxima). No obstante, dicha posibilidad no es absoluta, puesto que condiciona la aplicación

\footnotetext{
${ }^{164}$ Las autoridades administrativas que han sido notificadas son: en Finlandia, el Consejo sobre Seguridad Social («Sosiaalilautakunta/Socialnämnd») y en Suecia, la Autoridad de Aplicación («Kronofogdemyndigheten») en https://e-justice. europa.eu/content_maintenance_claims-47-es.do

${ }^{165}$ En particular, se considera como tal: “a) un documento en materia de obligaciones de alimentos formalizado o registrado como documento público con fuerza ejecutiva en el Estado miembro de origen y cuya autenticidad: i) se refiera a la firma y al contenido del instrumento, y ii) haya sido establecida por un poder público $u$ otra autoridad autorizada a tal efecto, o bien b) un acuerdo en materia de obligaciones de alimentos, celebrado ante las autoridades administrativas del Estado miembro de origen o formalizado por ellas".

166 DOUE L 143 de 30 de abril de 2004, p. 15.

${ }^{167}$ DOUE L 147 de 10 de junio de 2009, p. 1.

${ }^{168}$ DOCE 192, de 22 de julio de 2011, p. 51.

${ }^{169} B O E$ de 12 de agosto de 1987.

${ }^{170}$ BOE de 11 de abril de 1995.
} 
de dicha normativa -convencional o estatal- al cumplimiento de una serie de condiciones (cláusula de eficacia máxima condicionada). Ello ocurrirá cuando tales normas establezcan bases más amplias para el reconocimiento de la decisión judicial extranjera, procedimientos simplificados más expeditivos para una solicitud de reconocimiento o una asistencia jurídica más favorable

Ahora bien, la cuestión está en saber si el CH 2007 resultará aplicable (o no) al reconocimiento de aquellas decisiones de alimentos procedentes de Estados miembros en el CH 2007 tras la disolución extrajudicial del matrimonio, como así sucede con las que proceden de Ucrania, Brasil, Nicaragua y Noruega. La respuesta a esta cuestión debe de ser en sentido afirmativo, puesto que el concepto de "resolución" que este convenio incorpora es amplio. Se aplica tanto al reconocimiento de las decisiones adoptadas por una autoridad judicial como administrativa incluyendo también los acuerdos celebrados ante dichas autoridades o aprobadas por ellas (art. 19.1 ${ }^{\circ}$ ).

Por su parte, España ha ratificado una serie de convenios bilaterales que incluyen en su ámbito de aplicación las obligaciones alimenticias, algunos de los cuales han sido desplazados en su aplicación por el RB-III (art. $69.2^{\circ}$ ), como así sucede con los convenios celebrados con Francia ${ }^{171}$ e Italia. Mientras que en otros supuestos no resultan de aplicación, bien porque excluyen la materia alimenticia de su ámbito de aplicación material, como así sucede con el convenio hispano-brasileño -al contemplar obligaciones de alimentos respecto de menores-, el convenio hispano-rumano y el hispano-mexicano, o bien porque incorporan un concepto restringido de "resolución judicial" entendiendo por tal las resoluciones dictadas por tribunales extranjeros, como así ocurre con el convenio hispano-colombiano (art. 1) o el hispano-chino (art. $\left.2.3^{\circ}\right)$.

Por el contrario, si resulta de aplicación lo dispuesto en el convenio hispano-ruso para las resoluciones judiciales dictadas en esta materia. No hay que olvidar que, según lo establecido en dicho ordenamiento jurídico, las cuestiones accesorias al divorcio extrajudicial son decididas posteriormente por una autoridad judicial.

57. Por su parte, no hay que olvidar la incidencia que este ámbito despliegan los mecanismos de cooperación internacional para garantizar los derechos concedidos al acreedor de alimentos a través de una resolución favorable. No se trata aquí de analizar en profundidad los diferentes instrumentos que vinculan a España en este ámbito, porque superaría el marco de este trabajo, sino de evidenciar que el reconocimiento o el reconocimiento y ejecución de una decisión de alimentos producida tras la disolución no judicial del divorcio puede ser fruto de la cooperación administrativa entre autoridades centrales. En el ámbito europeo el RB-III contiene todo un capítulo (VII) relativo a la cooperación administrativa, cuyo objeto, entre otros, es facilitar el reconocimiento de las decisiones adoptadas en otros Estados miembros. Teniendo en cuenta que dicho instrumento normativo desplaza, a su vez, tanto al Convenio de Nueva York de 20 de junio de 1956 sobre la obtención de alimentos en el extranjero (en adelante $\mathrm{CNY}^{172}$ ) como al CH 2007 -art. 69.2 $2^{\circ}$ RB-III-.

El RB-III podría ser de aplicación para obtener el reconocimiento o el reconocimiento y ejecución de aquellas decisiones procedentes de Portugal, Italia Rumania, Letonia y Estonia dictadas en este ámbito tras la disolución no judicial de un matrimonio. No obstante, si tenemos en cuenta que dicha norma, como hemos tenido oportunidad de analizar, cuenta con un concepto de "resolución judicial" restringido, la consecuencia es que dicha norma no podría ser aplicable al reconocimiento de tales decisiones. Las partes se verían obligadas a articular los mecanismos de cooperación que establece el CNY o el CH 2007 que prevalece sobre aquel.

En concreto, el CNY sería operativo frente aquellas decisiones de alimentos procedentes de Ucrania, Moldavia, México, Colombia, Ecuador, Kirguistán y Dinamarca; mientras que el CH 2007 lo será frente a las que proceden de Noruega, siempre que este instrumento sea más favorable al reconocimiento que lo dispuesto en el CL, y las dictadas en el ámbito europeo (Rumania, Letonia, Estonia, Italia y Portugal)

\footnotetext{
${ }^{171}$ Convenio entre España y Francia sobre el reconocimiento y ejecución de decisiones judiciales y arbitrales y actas auténticas en materia civil mercantil, firmado en París el 28 de mayo de 1969 (BOE de 14 de marzo de 1970).

${ }^{172}$ BOE de 24 de noviembre de 1966.
} 
58. Por último, y en defecto de normativa institucional e internacional o, en aquellos casos, en los que esta resulte más favorable (ex arts. 23 del CH 1973 de reconocimiento y del CH 1958, art. $52 \mathrm{CH}$ 2007) será de aplicación el régimen autónomo o estatal. Este se encuentra previsto tanto en la LCJIMC como en los arts. 11 y 12 de la LJV. Aplicar lo dispuesto en una u otra normativa dependerá de cuál sea el efecto pretendido.

59. Mención especial merece saber qué sucede con las pensiones de alimentos obtenidas tras la disolución privada de un matrimonio obtenido en Francia. No resultaría aplicable el RB-III, como así ha dispuesto la Circular de 26 de enero de 2007 (Ficha 10), puesto que ni constituye una "resolución judicial" ni tampoco una "transacción judicial" o un "documento público" en el sentido que dicha disposición establece ${ }^{173}$. Tampoco sería de aplicación las disposiciones que el convenio bilateral hispanofrancés establece para el reconocimiento de decisiones judiciales, puesto que este solo se aplica al reconocimiento de "resoluciones recaídas en procedimientos contenciosos o voluntarios (art. 2.1 $1^{\circ}$ )". No obstante, sí podría ser de aplicación el régimen legal previsto para el reconocimiento de actas auténticas o documentos públicos (art. 14), siempre que, como así exige el convenio, en la ley del Estado de origen del mismo, es decir, en Francia, dicho documento tuviera fuerza ejecutiva (art. 2.6 $6^{\circ}$ ). En caso contrario, la única vía para que dicho acuerdo fuera reconocido en España es que los cónyuges integraran la aportación a la manutención y educación de los hijos en un acto auténtico, o bien solicitar la homologación de dicho pacto ante la autoridad judicial competente, siempre que ello resultara factible ${ }^{174}$.

\section{Relaciones paternofiliales}

60. Menor dificultad existe a la hora de determinar el régimen de reconocimiento y ejecución de decisiones extranjeras sobre custodia y/o derecho de visita obtenidas tras la disolución no judicial de un matrimonio, puesto que, aunque existe un amplio abanico de instrumentos normativos en vigor en nuestro país en este ámbito (institucional, convencional y estata ${ }^{175}$ ), son relativamente pocos los países que contemplan la posibilidad de obtener un divorcio no judicial cuando existen hijos menores o incapacitados. En particular, este dilema se plantea solo cuando se pretenda obtener en España el reconocimiento de tales decisiones obtenidas tras la disolución de un matrimonio no judicial procedente de Portugal, Francia, Moldavia, Estonia, Rumania, Dinamarca, Colombia, China, Japón y Cuba -únicos países que contemplan esta modalidad de disolución del matrimonio cuando hay menores de edad-.

61. El primero de los problemas al que inevitablemente se habrá de enfrentar la autoridad española ante la que se haga valer tales decisiones será determinar qué instrumento normativo será el que, en el caso concreto, deberá ser aplicado para decidir si la decisión en cuestión resultará o no susceptible de ser reconocida y, por ende, de desplegar en nuestro país los efectos que de la misma se pretendan.

No hay duda alguna, a partir del concepto de "resolución judicial/órgano jurisdiccional" que el RBr II bis incorpora, que las disposiciones previstas en dicho instrumento serán aplicables al reconocimiento de las decisiones de custodia y derecho de vistan que hubieran sido contempladas tras la disolución no judicial de un matrimonio obtenido en Portugal, Rumanía y Estonia; normas que prevalecen sobre el Convenio de Luxemburgo de 20 de mayo de 1980, relativo al reconocimiento y a la ejecución de decisiones en materia de custodia de menores, así como al restablecimiento de dicha custodia ${ }^{176}$-en adelante Convenio de

\footnotetext{
${ }^{173}$ Sobre las dificultades para reconocer una obligación de alimentos pactada en un divorcio contractual francés, vid. P. HАMмJE, "Le divorce par consentement...", lo.cit., p. 148.

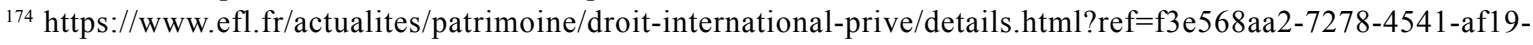
$86136 \mathrm{c} 0396$

${ }^{175}$ Un análisis de la misma en R. RuEda VAldivia, "Custodia y derecho de visita en las rupturas de pareja de dimensión transfronteriza: breve aproximación a su regulación en derecho internacional privado español”, en M.C. GARCÍA CARNICA/ N. Marchal Escalona (Dir.), g. MOREno CoRdero, A. Quesada PÁEZ (Coords.), Aproximación interdisciplinar a los retos actuales de protección de la infancia dentro y fuera de la familia, Navarra, Aranzadi, 2019, pp. 521-524.

${ }^{176}$ BOE de 1 de septiembre de 1984.
} 
Luxemburgo- [art. 60 d) RB II bis] y el Convenio de la Haya de 19 de octubre de 1996, relativo a la competencia, la ley aplicable, el reconocimiento, la ejecución y la cooperación en materia de responsabilidad parental y de medidas de protección de los niños ${ }^{177}$-en adelante CLH 1996- [art. 60 d) RB II bis].

El RBr II bis sería también susceptible de aplicación, según lo expuesto supra, para reconocer aquellas decisiones que hubieran sido acordadas en este ámbito tras un divorcio privado obtenido en Francia. Podrían obtener eficacia en España, bien a través del reconocimiento automático, o bien del execuátur, según cual fuera el efecto pretendido. No obstante, no sería de aplicación el régimen dispuesto para la libre circulación de las decisiones adoptadas en materia de Derecho de visita ex art. 41 RB II bis, puesto que para aplicar lo dispuesto en dicho capítulo se exige que exista una resolución judicial ejecutiva (Ficha 10 Circulaire du 26 janvier 2017).

Mención especial merece lo dispuesto en el RB II bis refundido en este ámbito, al prever que los documentos públicos y los acuerdos entre partes en materia de responsabilidad parental que tengan fuerza ejecutiva en un Estado miembro deberán ser asimilados a «resoluciones» a efectos de la aplicación de las normas sobre reconocimiento y ejecución (art. $65.2^{\circ}$ ). Por consiguiente, tales decisiones deberán seguir, cuando dicho Reglamento entre en vigor, dicho régimen.

62. Por su parte, en relación con aquellas decisiones de custodia y derechos de visita procedentes de Noruega, Dinamarca y Moldavia podrían resultar de aplicación tanto lo dispuesto en el CLH 1996, aplicable al reconocimiento de toda medida de protección adoptada en un Estado miembro, como en el Convenio de Luxemburgo al adoptar un concepto amplio de "resolución", que considera como tal a toda resolución de una autoridad, en la medida en que se refiera al cuidado de la persona del menor o al derecho de visita [art. $1^{\circ} \mathrm{c}$ )]. Para determinar cuál de los dos convenios sería de aplicación, habría de estar a lo dispuesto en las cláusulas de concurrencia o de compatibilidad. El problema está en que los dos convenios se limitan a declarar la compatibilidad de sus normas con otros instrumentos convencionales (arts. 19 Convenio de Luxemburgo y $52.1^{\circ} \mathrm{CH} 1996$, respectivamente). De ahí que los conflictos que en este ámbito se puedan plantear se hayan de solventar, necesariamente, en atención al principio de eficacia máxima, principio que, en nuestro caso, determinará que se acabe aplicando el Convenio que resulte más favorable al reconocimiento. Por su parte, aquellas decisiones procedentes de Cuba serán reconocidas en España a través de lo dispuesto en el CH 1996.

63. España cuenta en este ámbito, además, con una serie de convenios bilaterales susceptibles de ser aplicados. No obstante, su eficacia práctica es nula, puesto que aquellos solo se aplican al reconocimiento de resoluciones judiciales procedentes de órganos jurisdiccionales, como así ocurre con el convenio hispano-chino (art. 16.3 ${ }^{\circ}$ y el hispano-colombiano (art. 1).

64. Por último, y en defecto de normativa institucional e internacional, será de aplicación el régimen autónomo o estatal. En particular, este será aplicable al reconocimiento de aquellas decisiones procedentes sobre guarda y custodia y derecho de visita procedente de China, Colombia y Japón. El régimen estatal se encuentra diseñado tanto en la LCJIMC como en los arts. 11 y 12 de la LJV, que serán de aplicación según cual sea el efecto pretendido.

\section{Conclusiones}

65. La disolución no judicial del matrimonio está adquiriendo en los últimos tiempos una importancia práctica innegable. Cada vez son más los Estados que, para descargar de trabajo a los órganos jurisdiccionales y agilizar trámites, atribuyen facultades o competencias a autoridades no judiciales para disolver un matrimonio. La intención del presente trabajo es analizar la eficacia en España de este tipo de divorcios obtenidos en el extranjero. El propósito fundamental del mismo es exponer el grado de dificultad que conlleva para el operador jurídico concretar cuál es el régimen de reconocimiento que resulta aplicable.

${ }^{177}$ BOE de 2 de diciembre de 2010. 
66. La diversidad existente en Derecho comparado evidencia que ni en todos los supuestos interviene una autoridad ni cuando interviene esta desarrolla la misma función, lo que repercute indudablemente, como hemos demostrado, en la eficacia extraterritorial de tales divorcios en nuestro país.

Asimismo, los diferentes pronunciamientos que pueden obtenerse tras la disolución no judicial de un matrimonio (alimentos, liquidación del régimen económico, responsabilidad parental), así como la pluralidad de fuentes normativas existente en el sistema jurídico español (institucional, convencional y estatal) y la diversidad con la que tales normas definen el concepto de "resolución judicial" a efectos de su aplicación, complica, sobremanera, saber cómo se reconoce en España el divorcio no judicial obtenido en el extranjero.

67. Hemos constatado que el régimen jurídico aplicable al reconocimiento de un divorcio no judicial obtenido en el extranjero depende principalmente del tipo de divorcio no judicial que se obtenga, es decir, si en este ha intervenido una autoridad no judicial desempeñando una función constitutiva o meramente recepticia de la voluntad de los cónyuges, o se trata de un mero divorcio privado en el que no ha intervenido autoridad alguna.

Mayores son los problemas que existen para reconocer en España los divorcios privados, incluso si posteriormente son visados por autoridad extranjera, como se evidenció en el asunto Sahyouni, al carecer en DIPr. español de una norma que determine la ley conforme a la cual proceder a su reconocimiento, consecuencia de la desafortunada decisión de política legislativa adoptada de modernizar y simplificar hasta liquidar el contenido del art. $107.2^{\circ}$ Código civil.

No sucede lo mismo con el divorcio privado francés. Este puede circular libremente entre los Estados miembros del RB II bis, lo que, a nuestro juicio, resulta no solo criticable, sino que evidencia los excesos y los peligros a los que conduce tanto el principio de confianza europea, como la idea pro reconocimiento que se está expandiendo en los últimos tiempos en las relaciones familiares.

68. Por su parte, concretar cual el régimen del reconocimiento aplicable a los divorcios otorgados por autoridad no judicial extranjera es una cuestión mucho más compleja que dependerá del país del que proceda dicho divorcio, de la fecha de su pronunciamiento y del efecto que se pretenda obtener con su reconocimiento (constitutivo, probatorio, registral, cosa juzgada o ejecutivo). A todo ello hay que sumar que, tales autoridades pueden tener competencia no solo para disolver el matrimonio, sino además para pronunciarse sobre otras cuestiones accesorias al mismo (alimentos, guarda y custodia, liquidación del régimen económico matrimonial).

Concretar cuál es la norma aplicable a su reconocimiento es una tarea difícil, no solo porque las partes pueden pretender el reconocimiento de todos los pronunciamientos (reconocimiento total) o solo de una parte del mismo (reconocimiento parcial), sino también por la pluralidad de fuentes normativas (institucional, convencional y estatales) que existe en Derecho español. Mucha mayor es la complejidad si se repara en un dato, y es que, en ocasiones, la disolución del vínculo y las cuestiones accesorias a la misma, en particular, las relativas a la disolución y liquidación del régimen económico del matrimonio pueden constar formalmente en documentos diferentes, como así sucede en aquellos divorcios procedentes de Estados que exigen la liquidación previa del régimen matrimonial para acceder a este tipo de divorcios.

Con todo, el dato a tener en cuenta para determinar el régimen jurídico aplicable al reconocimiento de tales divorcios en España es si la función que desempeña la autoridad que lo pronuncia es o no equivalente a la que realizan las autoridades judiciales españolas cuando disuelven un vínculo matrimonial.

A la vista de esta realidad, no cabe sino propugnar una especialización en la disciplina por parte los profesionales especialmente vinculados al Derecho de familia. 